\title{
Paleotethyan faunal/floral evidence in the Mississippian Maritimes Basin of Canada: An overview
}

\author{
Pedro Cózar ${ }^{1 *}$ ๑) and Ian D. Somerville ${ }^{2}$ \\ ${ }^{1}$ Instituto de Geociencias (CSIC, UCM), Ciudad Universitaria, 28040 Madrid, Spain <p.cozar@igeo.ucm-csic.es> \\ ${ }^{2}$ UCD School of Earth Sciences, University College Dublin, Belfield, Dublin 4, Ireland <ian.somerville@ucd.ie>
}

\begin{abstract}
In this study, middle to late Mississippian microfossil assemblages from the Maritimes Basin of eastern Canada (Nova Scotia, SW Newfoundland, and New Brunswick) are closely compared to those from Western Paleotethys basins. The comparison is focused mainly on foraminifers and calcareous algae. Most foraminifers and algae described from the Maritimes Basin are considered cosmopolitan, and the occurrence in western Europe and northern Africa of taxa previously considered endemic to the North America Realm suggests a close paleobiogeographic relationship. This European/African correlation is further supported by other foraminiferal/algal taxa, the importance of which were previously overlooked, including: Plectogyranopsis ex gr. P. hirosei (Okimura, 1965), Mikhailovella Ganelina, 1956, Koktjubina windsorensis (Mamet, 1970), Polysphaerinella bulla Mamet, 1973, Mstinia Dain in Dain and Grozdilova, 1953, Haplophragmina Reitlinger, 1950, Omphalotis Shlykova, 1969, Pseudolituotuba Vdovenko, 1971, Pseudoendothyra Mikhailov, 1939, Saccamminopsis (Sollas, 1921) Vachard and Cózar, 2003, Kamaenella Mamet and Roux, 1974, and Anthracoporellopsis Maslov, 1956. Some species recorded in the Maritimes Basin have been typically recorded in Britain and Ireland in the southern platform of Laurussia. This implies a connection via the Rhenohercynian Ocean, whereas statistical analyses suggest that Maritimes Basin assemblages are closer to those of the Gondwana platform, which could have been established via the Paleotethys Ocean, and also with terranes northwest of the Variscan Front, in which its most logical connection should be with a still-open Rheic Ocean during the Visean and early Serpukhovian. Those taxa demonstrate a more-or-less continuous faunal and microfloral interchange between the Maritimes Basin and the Western Paleotethys paleobiogeographic realm. Furthermore, the width of the Paleotethys and Rheic oceans separating these regions is not considered excessive, particularly during the late Visean and early Serpukhovian.
\end{abstract}

\section{Introduction}

The Maritimes Basin of Atlantic Canada comprises Middle Devonian to early Permian strata (Gibling et al., 2019) and includes SW Newfoundland, Nova Scotia, and New Brunswick (Fig. 1). Its underlying substrata are composed of a series of amalgamated terranes of peri-Gondwanan affinity that drifted from Gondwana during Ordovician times (e.g., Waldron et al., 2015; Gibling et al., 2019) or even from the Proterozoic/early Cambrian (e.g., Landing, 2005). By the Middle Devonian, these terranes were supposedly attached to the North American craton (e.g., van Staal et al., 1998; Murphy et al., 2004). This episode is related to the closure of the Rheic Ocean (Fig. 2) that started in the Early Devonian and by the early Carboniferous was considered according to some authors essentially closed (e.g., Nance et al., 2012, and references therein). McKerrow et al. (2000) considered that the Rheic Ocean was open during the Devonian and the collision occurred during the early Carboniferous. During the Devonian, the ocean was not wide enough to prevent the migration of key fauna. A similar scenario was adopted by Torsvik and Cocks $(2004,2013)$, although they

\footnotetext{
*Corresponding author
}

considered the relatively narrow Rheic Ocean was located northward of Armorica. South of Armorica, Torsvik and Cocks (2004, 2013) interpreted a wide Paleotethys Ocean, with Gondwanaland displaced to a more southerly position. Since the Middle Devonian, Stampfli and Borel (2002) only considered a vast Paleotethys Ocean to the south, and the Rhenohercynian Ocean to the north, separated by the macro-European Hunic terrane. In contrast, Stampfli et al. (2013) considered a wide Rheic Ocean during the Frasnian and Famennian (Upper Devonian) between the Meguma/Avalonia terranes and the newly formed continent (Laurussia). Stampfli et al. (2013) considered that closure of the Rheic Ocean occurred during the Tournaisian, coincident with opening of the Paleotethys Ocean to the south.

It must be taken into consideration that tectonic models developed for the Maritimes Basin by North American researchers are usually related to the Alleghenian orogeny, and that this zone is typically compared with the Appalachian style (e.g., Waldron et al., 2015; Gibling et al., 2019). This is illustrated by the postulated collision of the terranes with the North American part of Laurussia during Devonian times. Eastern Appalachian tectonic units have been correlated with those in Britain and Ireland, suggesting a pre-collision (Devonian) separation of $\sim 800 \mathrm{~km}$ between Newfoundland and Ireland (Waldron et al., 2018). 


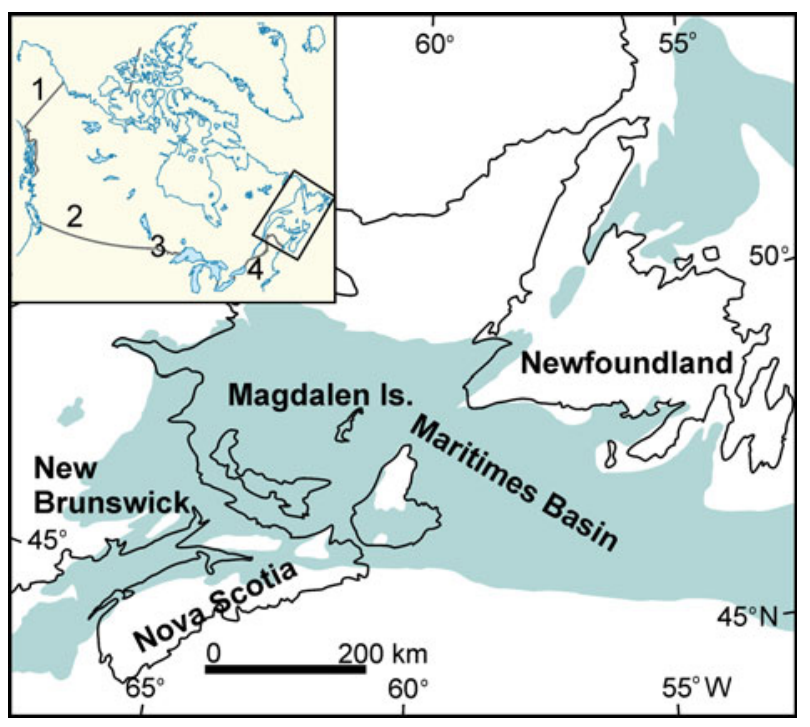

Figure 1. The Maritimes Basin of Atlantic Canada (shaded). Inset map shows location of the Maritimes Basin in North American craton and other regions/ basins cited in the text. $1=$ Alaska; $2=$ Alberta (Western Cordillera); $3=$ MidContinent; 4 = Appalachians.

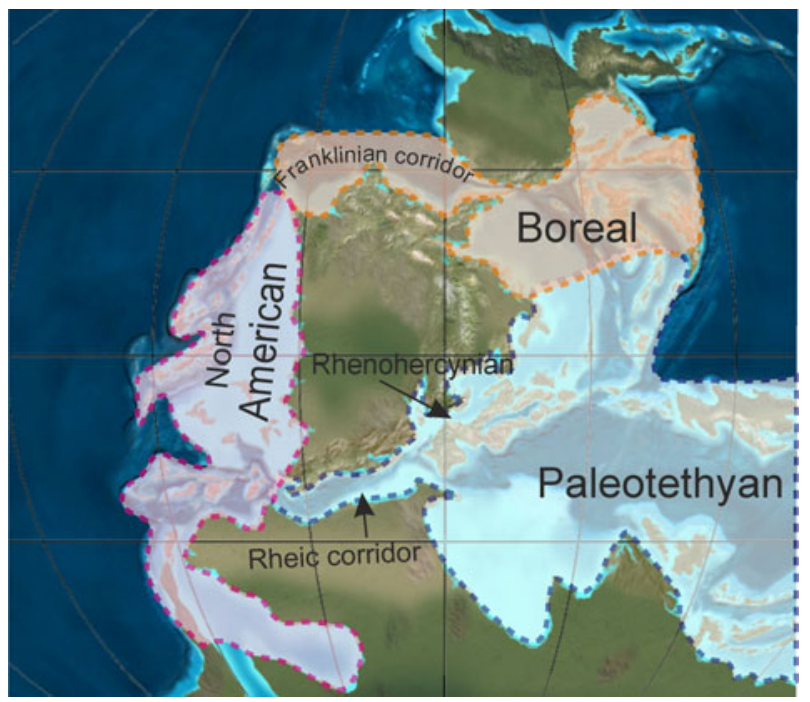

Figure 2. Late Viséan-Serpukhovian paleogeography and paleobiogeography (modified from 340-325 Ma map of Blakey, 2013).

Facies and tectonic models reflecting similarities between Mississippian rocks in Ireland and the Maritimes Basin were first claimed by Belt $(1929,1944,1969)$, and the first faunal arguments corroborating this hypothesis based on rugose corals were published contemporaneously (Lewis, 1935). Nevertheless, the general paleogeographic models disagree, and the idea has not been unanimously accepted by all authors who have studied the diverse fauna and microflora. These later authors supported the hypothesis that the Maritimes Basin was closer to the American Appalachians than to Europe (e.g., Globensky, 1967; Mamet, 1968, 1970; Jansa and Mamet, 1984). Other authors have progressively revealed new data that disagree with this distant paleogeographic position for the

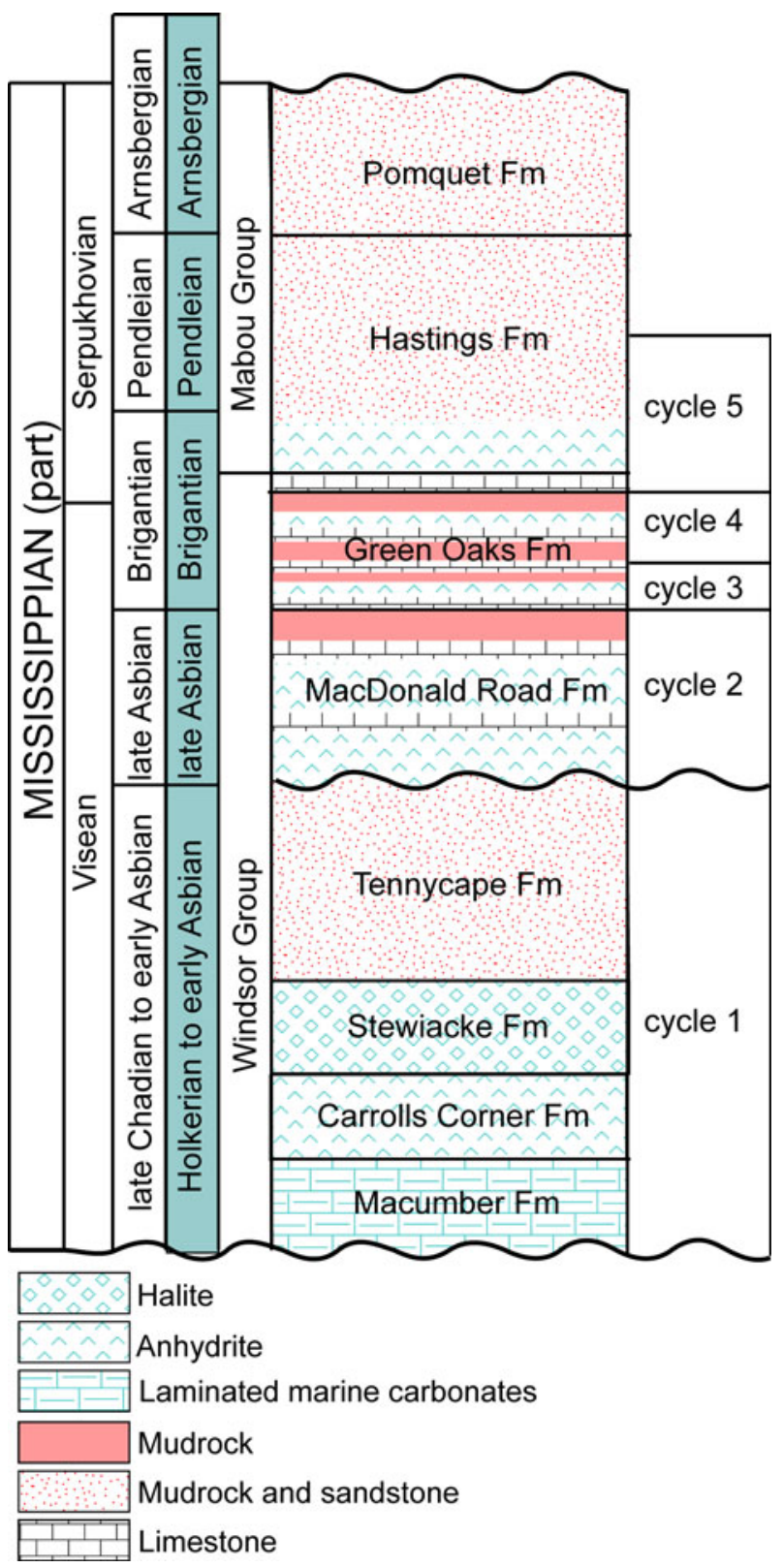

Figure 3. Simplified stratigraphic succession for the Windsor Group in Nova Scotia. Biostratigraphic age determinations: shaded column from Jutras et al. (2015); white column according to von Bitter et al. (2007). Cycles 1-5 as defined by Giles (1981). Fm = Formation

Maritimes Basin and Europe, showing additional sedimentological similarities between the Maritimes Basin and Ireland/Britain (Giles, 1981, 2009; Mitchell, 1992; von Bitter et al., 2007). Transgressive-regressive events have been recognized in the Visean Windsor Group (e.g., Giles, 1981, 2009; Fig. 3), which were compared with the major cycles defined in northern England by Ramsbottom (1973). Mitchell (1992) showed unconformities with similar timing and duration, and similar fault control for basin initiation and subsidence, and thus, stratigraphic similarities between the Maritimes Basin and Northern Ireland. All of those previous studies, as well as some faunal and floral similarities, were summarized by von Bitter et al. (2007). 
Giles (1981) described five cycles in the Windsor Group (A-E or 1-5 auct.; Fig. 3), of which cycles 2-5 show similarities with the cycles defined in the Asbian-Brigantian of Ireland and northern England (von Bitter et al., 2007). However, cyclic sedimentation interpreted as glacioeustatic-driven transgressiveregressive sequences for the late Visean and Serpukhovian, as shown in detail by Giles (2009), are not exclusive to Ireland and England (Yoredale cyclothems) being common in Belgium/ northern France (e.g., Hance et al., 2001), the North American Midcontinent (e.g., Smith and Read, 2000), and even in Saharan basins of the Gondwana platform (e.g., Bourque et al., 1995; Cózar et al., 2014, 2016b).

Faunal and floral similarities between the Maritimes Basin and Ireland/Britain have been highlighted in previous publications (von Bitter, 1976; von Bitter and Plint-Geberl, 1982; Clayton, 1985; Utting, 1987; Purnell and von Bitter, 1992; Poty, 2002; Utting and Giles, 2004; von Bitter and Legrand-Blain, 2007). Most data are based on rugose corals, conodonts, brachiopods, and miospores.

This study is primarily focused on two groups of microfossils: foraminifers and calcareous algae (including problematic algae). Both groups are widespread in most carbonate platform facies during the Mississippian and are distributed over a vast geographic area suitable for paleobiogeographic comparisons. The aim of this study is to highlight species of foraminifers and calcareous algae that are recorded in western Europe/ northern Africa and the Maritimes Basin, and those recorded in the North American Realm, whose migration routes might have passed through the Maritimes Basin.

\section{Material and methods}

A revision of individual foraminiferal/algal taxa is included for which plausible paleobiogeographical affinities are discussed. This section is based purely on the presence/absence of different taxa in the Maritimes Basin as well as in other basins in Europe, North Africa, or North America.

To compare the paleobiogeography of the Maritimes Basin, foraminifers (excluding unilocular genera) and algae (including problematic algae) of the late Visean and Serpukhovian were selected from the following regions: Midcontinent/ Appalachians, Britain/Ireland, SW Spain (including basins in the northern Ossa-Morena and southern Central Iberian zones), Moroccan Meseta (mostly western Meseta), NW Spain (Cantabrian Mountains), southern France (including Montagne Noire, Mouthoumet, and Pyrenees), and the Saharan basins of Morocco and Algeria (including the Tindouf and Béchar basins). The database from the Maritimes Basin is mostly based on Mamet (1968, 1970), Brisebois (1979), Jansa and Mamet, (1984), Poty (2002), and von Bitter and Legrand-Blain (2007) (see Tables 1, 2).

To avoid a long list of publications, recent studies that have previously compiled taxonomic databases are preferred herein, and thus the database on foraminifers contains 110 genera based on Davydov and Cózar (2019, and references therein). The database on algae contains 74 genera compiled from Mamet (1991, 1992, 1995b, 2002), Cózar and Vachard (2003, 2005), Pille (2008), Vachard and Cózar (2010), and Vachard et al. (2016).
A binary presence/absence database was analyzed using the PAST v.3.14 software (Hammer, 2016). The Jaccard and Raup and Crick similarity indices were calculated in the cluster using paired linkage (UPGMA). Nonmetric multidimensional scaling (NMDS) was also applied to graphically express the similarity indices among the regions. The Raup-Crick coefficient was used because it minimizes the result of overweighting widely distributed species and is less affected by sampling bias (Raup and Crick, 1979). The database was analyzed at the generic level, because (as demonstrated by Cózar et al., 2018 and Davydov and Cózar, 2019) there was no significant difference with the analysis at the specific level, and it prevents more frequent contradictory interpretations resulting from the species comparison due to more uneven data.

Repositories and institutional abbreviations.-The algal and foraminiferal collections of thin sections used for the statistical analysis are deposited in the following institutions: Royal Ontario Museum, Canada (studies by P. von Bitter); National Museum of Natural History, Washington DC, USA (studies by R.G. Browne, D.E. N. Zeller, and M. Rich); University of Colorado Museum, Boulder, USA (studies by P. Brenckle; part of the collection from northern Arkansas is still in the possession of the author); Institut Royal des Sciences Naturelles de Belgique, Brussels (part of the studies after 2000 by B.L. Mamet); Université de Liège, Belgium (studies by R. Conil and M. Laloux); Université Paul-Sabatier, Toulouse, France (studies by L. Pille); Université de Lille 1, France (studies by D. Vachard); British Geological Survey, Keyworth, UK (studies by I. Burgess and by A.R.E. Strank, C.N. Waters, I. Burgess, and P. Cózar from boreholes in northern England); British Geological Survey, Edinburgh, UK (studies by P. Cózar from boreholes in the Midland Valley of Scotland); University College Dublin, Ireland (studies by I.D. Somerville and S. Gallagher); Université Moulay Ismail, Meknès, Morocco (studies by M. Berkhli); Institute Scientifique de Rabat, Morocco (studies by A. Tahiri); Université Cadi Ayyad, Marrakech, Morocco (studied by A. Tourani); Paleontological Collection, Universidad Complutense de Madrid, Spain (studies by P. Cózar= PC). The collection of M.-F. Perret is lost (personal communication, M.-F. Perret, 2015). The repository of B. Mamet's pre-2000 samples referred to in this study is unknown (personal communication, A. Préat, 2021).

\section{Algae and problematic algae}

A detailed revision of the Carboniferous calcareous algae was published by Mamet (1991), with the main paleobiogeographic aspects more extensively developed by Mamet (1992). These studies summarized knowledge of the calcareous algae in the twentieth century and include a vast paleobiogeographic and biostratigraphic database. However, as Mamet (1991) recognized, the algal nature of numerous taxa used in his paleobiogeographic analysis is rather questionable (e.g., Cylindrofolia Brenckle and Groves, 1987, and Eolithoporella Johnson, 1966). He recognized 135 valid genera with 276 species distributed in three major realms (Fig. 2)-North America, Paleotethys, and Arctic (= Boreal)—subdivided into eight 
Table 1. Revised late Visean-Serpukhovian algae and problematic algae from the Maritimes Basin, Midcontinent/Appalachian, and western Paleotethys. $0=$ absent; $1=$ present.

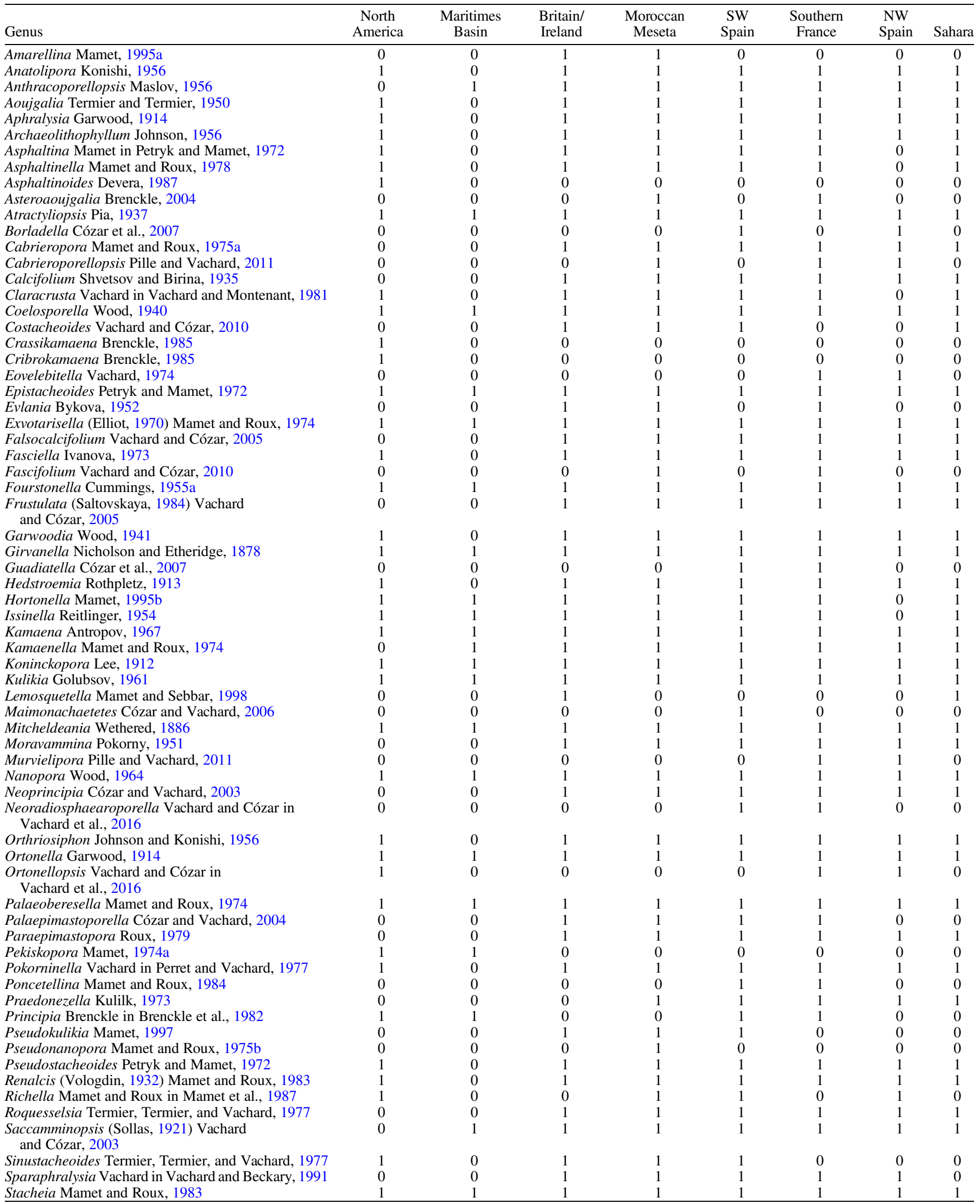


Table 1. Continued.

\begin{tabular}{|c|c|c|c|c|c|c|c|c|}
\hline Genus & $\begin{array}{c}\text { North } \\
\text { America }\end{array}$ & $\begin{array}{c}\text { Maritimes } \\
\text { Basin }\end{array}$ & $\begin{array}{l}\text { Britain/ } \\
\text { Ireland }\end{array}$ & $\begin{array}{l}\text { Moroccan } \\
\text { Meseta }\end{array}$ & $\begin{array}{l}\text { SW } \\
\text { Spain }\end{array}$ & $\begin{array}{l}\text { Southern } \\
\text { France }\end{array}$ & $\begin{array}{l}\text { NW } \\
\text { Spain }\end{array}$ & Sahara \\
\hline Ungdarella Maslov, 1950 & 1 & 0 & 1 & 1 & 1 & 1 & 1 & 1 \\
\hline Valuzieria Termier, Termier, and Vachard, 1977 & 0 & 0 & 0 & 1 & 0 & 1 & 0 & 0 \\
\hline $\begin{array}{l}\text { Windsoporella (Mamet and Rudloff, 1972) } \\
\text { Vachard, } 1980\end{array}$ & 1 & 1 & 1 & 1 & 1 & 1 & 1 & 1 \\
\hline Zidella Saltovskaya, 1984 & 0 & 0 & 1 & 1 & 1 & 1 & 1 & 1 \\
\hline Total & 42 & 23 & 54 & 60 & 59 & 61 & 49 & 49 \\
\hline
\end{tabular}

subrealms. Approximately half of the calcareous algae were considered cosmopolitan (49 genera) or of generalized dispersion (16 genera), but more important for the paleobiogeographic studies, are the endemic taxa to these three realms. The Paleotethys is the most diverse realm containing up to 38 endemic genera.

The geographic distribution of several genera has been updated since Mamet's (1991, 1992) database, resulting in modification of the distribution of some taxa. Mamet (1968, 1970) and mostly Jansa et al. (1978) identified a total of 31 taxa from different localities in the Maritimes Basin, of which Windsoporella (Mamet and Rudloff, 1972) Vachard, 1980 and Pekiskopora Mamet, 1974c were considered endemic to the North American Realm, with the rest of the assemblages as cosmopolitan or of generalized distribution. Similar taxa were also recorded by Brisebois (1979). The diversity and richness of algae in the Maritimes Basin are difficult to assess because: (1) the possible influence of deep oceans and cold water platforms/currents that did not permit a widespread settlement of the dasycladales (Jansa and Mamet, 1984); (2) limited documentation of these algal assemblages available in only a few publications, even in the absence of illustrations; and (3) variable but often-poor preservation in most of the carbonates in the Windsor Group of Nova Scotia and Codroy Group of Newfoundland, which are often dolomitized or composed of evaporites (Mamet, 1970; Jansa et al., 1978).

Windsoporella was originally considered as an algal genus endemic to the North American Realm, but has been recorded, rarely, in the eastern Paleotethys realm (Vachard, 1980) and subsequently commonly recorded in western European/northern African basins (see revision of the genus Windsoporella by Cózar et al., 2009; Pille and Vachard, 2011).

Jansa et al. (1978) illustrated Pekiskopora sp. (endemic to the North American realm), although it cannot be unquestionably attributed to that genus because of its poor preservation. In those specimens, only the outer morphology is preserved, a feature that does not allow a reliable identification of Pekiskopora, and in general, of any dasycladal algae. Furthermore, the outer morphology is rather like that of other coeval dasycladal algae, e.g., Kulikia Golubsov, 1961. Pekiskopora was also documented (but not illustrated) by Brisebois (1979) in limestones of Brigantian age on the Magdalen Islands in the central Gulf of St. Lawrence (Fig. 1). Although the identification cannot be confirmed at either of these widely separated localities in the Maritimes Basin, its reported presence continues to signal an American connection.

Additional remarks on the algal assemblages need to be highlighted. First, the Maritimes Basin is notable for the occurrence of Kamaenella Mamet and Roux, 1974, a typical Western Paleotethyan genus that does not occur in other regions of North America. Kamaenella thickets are common in many upper Visean platforms from Ireland and England (Gallagher, 1996; Horbury and Adams, 1996; Cózar and Somerville, 2005b). Nevertheless, quantification of the calcareous algae listed by Jansa et al. (1978) was not documented, and thus, it is not possible to precisely establish whether it contributes to similar thickets. Second is the occurrence (although rare) of Saccamminopsis (Sollas, 1921) Vachard and Cózar, 2003 in the Maritimes Basin. This problematic alga was attributed to the Udoteacea algal reproductive organs by Vachard and Cózar (2003), although it was previously attributed to the dasycladal algae (Skompski, 1986), and recorded only in the Paleotethys realm (see distribution of Vachard and Cózar, 2003). In Ireland and northern England, this taxon commonly occurs as 'floods,' i.e., rich concentrations in bands in upper Visean limestones (e.g., Hallett, 1971; Gallagher and Somerville, 1997; Cózar and Somerville, 2005b). Its occurrence in the Maritimes Basin has never been documented as flood-like deposits, but its occurrence 'outside' of the Paleotethys realm is significant enough by itself. Third is the presence of the problematic alga Anthracoporellopsis Maslov, 1956, a taxon reported by both Jansa et al. (1978) and Brisebois (1979), and restricted to the Paleotethys realm and the Canadian Arctic (Vachard and Cózar, 2010).

As a consequence of the above data, the assemblages of the Maritimes Basin do not contain unquestionable algal or problematic algal genera endemic to the North American Realm in the assemblages of the Maritimes Basin, because the identification of Pekiskopora could not be confirmed and the recrystallized specimens are more similar to the outer morphology of Kulikia (a cosmopolitan taxon). In addition, Pekiskopora is recorded only in the Tournaisian, and thus its occurrence in the late Visean of the Maritimes Basin seems implausible. In contrast, there are at least three typical Paleotethyan genera present: Kamaenella, Saccamminopsis, and Anthracoporellopsis.

Another significant algal taxon for paleobiogeographic interpretations is Albertaporella Johnson, 1966, described as an early Visean endemic genus in the North American Cordillera (Johnson, 1966; Mamet, 1991) and New Mexico (Armstrong et al., 1992); it has also been recorded in the early Visean of SE Ireland (Cózar and Somerville, 2005a). The most logical explanation is that the taxon migrated via the Rheic corridor (Fig. 2), because there is no record of Albertaporella in the Arctic realm (Mamet and Preat, 2010), and thus, migration by the Franklinian corridor in the Boreal Ocean is discarded (Fig. 2). The apparent absence of Albertaporella in the Maritimes Basin can be explained by the absence of more 
Table 2. Revised late Visean-Serpukhovian foraminifers from the Maritimes Basin, Midcontinent/Appalachian, and western Paleotethys (unilocular genera excluded). $0=$ absent; 1 = present.

\begin{tabular}{|c|c|c|c|c|c|c|c|c|}
\hline GENERA & $\begin{array}{c}\text { North } \\
\text { America }\end{array}$ & $\begin{array}{l}\text { Maritimes } \\
\text { Basin }\end{array}$ & $\begin{array}{l}\text { Britain/ } \\
\text { Ireland }\end{array}$ & $\begin{array}{l}\text { Moroccan } \\
\text { Meseta }\end{array}$ & $\begin{array}{l}\text { SW } \\
\text { Spain }\end{array}$ & $\begin{array}{c}\text { Southern } \\
\text { France }\end{array}$ & $\begin{array}{l}\text { NW } \\
\text { Spain }\end{array}$ & Sahara \\
\hline
\end{tabular}

Ammarchaediscus Conil and Pirlet in Pirlet

and Conil, 1977

Ademassa Vachard in Vachard et al., 1993

Ammovertella Cushman, 1928

Archaediscus Brady, 1873

Asteroarchaediscus Miklukho-Maklay in

Kiparisova et al., 1956

Bibradya Strank, 1983

Biseriella Mamet in Armstrong and Mamet, 1974

Bradyina Möller, 1878

Brenckleina Zaninetti and Altiner, 1979

Brownediscus Brenckle, Ramsbottom, and Marchant, 1987

Brunsia Mikhailov, 1935

Calcitornella Cushman and Waters, 1928

Calcivertella Cushman and Waters, 1928

Cepekia Vašíček \& Růžička, 1957

Chomatomediocris Vdovenko in Brazhnikova and Vdovenko, 1973

Climacammina Brady in Etheridge, 1873

Conilidiscus Vachard, 1988

Consobrinellopsis Krainer and Vachard, 2015

Cribrospira Möller, 1878

Cribrostomum Möller, 1879

Earlandia Plummer, 1930

Eblanaia Conil and Marchant in Conil, 1977

Endospiroplectammina Lipina, 1970

Endostaffella Rozovskaya, 1961

Endostaffellopsis Cózar et al., 2016a

Endotaxis Bogush and Brazhnikova in Aizenverg et al., 1983

Endothyra Phillips, 1846

Endothyranella Galloway and Harlton in Galloway and Ryniker, 1930

Endothyranopsis Cummings, 1955a

Eoendothyranopsis Reitlinger and Rostovzeva in

Reitlinger, 1966

Eolasiodiscus Reitlinger, 1956

Eoparastaffella Vdovenko, 1954

Eosforschia Mamet in Mamet et al., 1970

Eosigmoilina Ganelina in Kiparisova et al., 1956

Eostaffella Rauzer-Chernousova, 1948a

Eostaffellina Reitlinger, 1963

Euxinita Conil and Dîl in Conil et al., 1980

Florennella Conil in Groessens et al., 1982

Forschia Mikhailov, 1935

Forschiella Mikhailov, 1939

Globispiroplectammina Vachard, 1977

Globivalvulina Schubert, 1921

Globoendothyra Bogush and Juferev, 1962

Globoomphalotis Bogush, 1987

Glomodiscus Malakhova, 1973

Haplophragmina Reitlinger, 1950

Hemidiscopsis Cózar in Cózar et al., 2015

Holkeria Strank, 1982

Howchinia Cushman, 1927

Insolentitheca Vachard in Bensaid et al., 1979

Janischewskina Mikhailov, 1939

Kasachstanodiscus Marfenkova, 1978

Koktjubina Marfenkova, 1991

Koskinobigenerina Eickhoff, 1968

Koskinotextularia Eickhoff, 1968

Lituotubella Rauzer-Chernousova, 1948b

Loeblichia Cummings, 1955a

Magnitella Malakhova, 1975

Mediocris Rozovskaya, 1961

Mikhailovella Ganelina, 1956

Millerella Thompson, 1942

Millerella' Thompson, 1942

Mirifica Shlykova, 1969

Monotaxinoides Brazhnikova and Yartseva, 1956

Mstinia Dain in Dain and Grozdilova, 1953 
Table 2. Continued.

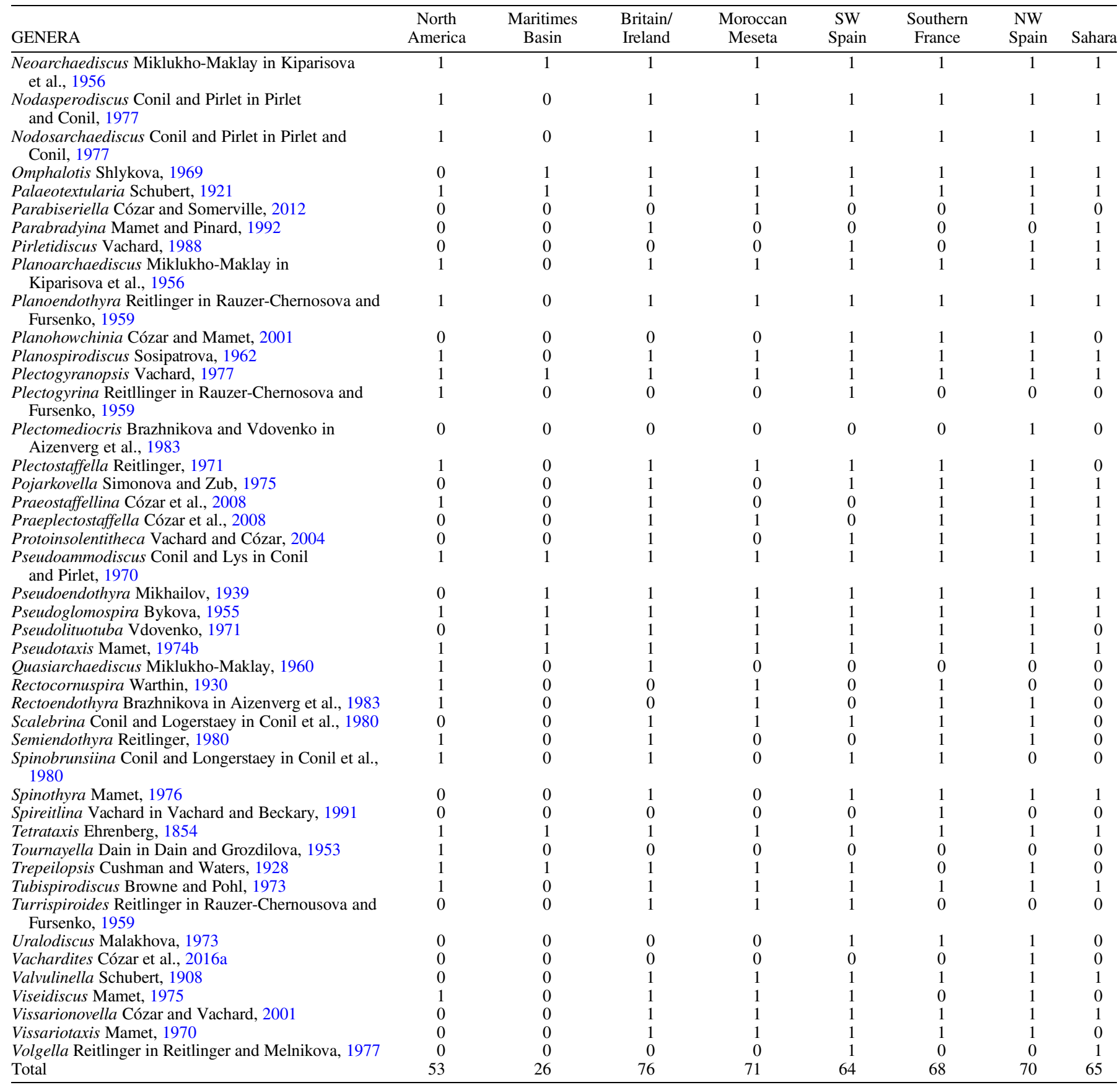

diverse and richer assemblages due to limited documentation to date, but also because the presence of early Visean strata in the Windsor Group is still debated; if present, these are mostly composed of thick evaporite deposits in cycle 1 (e.g., Jutras et al., 2015; Waldron et al., 2017; Fig. 3) that would themselves have formed an unfavorable environment.

\section{Foraminifers}

Despite the presence of numerous endemic genera, a clear exclusively worldwide provincialism does not seem to have existed within the Mississippian Fusulinata foraminifers. Mamet and
Skipp (1970a) and Mamet (1977) documented continuous interchange between the three main realms-Paleotethys, North American, and Boreal (Fig. 2) - but not exclusive provincialism. Ross (1995) introduced a fourth realm, called Panthalassa or Sonomia, including some terranes in parts of Japan, the southern Russian Far East, British Columbia, and New Zealand. In the Mississippian, geographic and stratigraphic distribution of foraminifers are better known than those of calcareous algae.

Previous data on Fusulinata foraminifers from the Maritimes Basin are restricted to a limited number of publications (Mamet, 1968, 1970; Brisebois and Mamet, 1974; Jansa et al., 1978; Brisebois, 1979; Jansa and Mamet, 1984). It is 
noteworthy that taxa recorded by Brisebois (1979) are rather similar to those of Jansa et al. (1978) and Mamet (1970), and they do not contribute to new occurrences of taxa. In total, $\sim 50$ taxa have been listed by the previous authors. Mamet (1970) based his attribution of the fauna to the North American Realm on the occurrence of Zellerinella Mamet, 1981, and mostly by the absence of some typical Paleotethyan taxa, e.g., Loeblichia Cummings, 1955 (Cummings, 1955a), Valvulinella Schubert, 1908, Omphalotis omphalota (Rauzer-Chernousova and Reitlinger in Rauzer-Chernousova et al., 1936), and Archaediscus karreri Brady, 1873. Jansa and Mamet (1984) further extended the comparison, including more detailed paleobiogeographic maps of the geographic distribution of Howchinia Cushman, 1927, Bradyina Möller, 1878, Lituotubella RauzerChernousova, 1948 (Rauzer-Chernousova, 1948b), and Omphalotis Shlykova, 1969 (all absent in the Maritimes Basin), and consideration that the distance between Newfoundland and Ireland was at least $1,000 \mathrm{~km}$ separated by a deep ocean, which did not permit faunal interchange, and rejecting contemporaneous paleogeographic reconstructions locating the Maritimes Basin close to Spain or the Moroccan Meseta.

Although most foraminifers recorded in the Visean-early Serpukhovian Windsor Group are cosmopolitan, their relative abundance is distinct in the different paleobiogeographic domains (Mamet, 1970, fig. 15), but could also be subject to paleoecological constraints (e.g., Mamet and Skipp, 1979). The basal Windsor Group strata comprises a thick interval of evaporites resting on a single marine carbonate unit (Macumber Formation), which defines the base of the group (Fig. 3) and provides the single potential source of foraminiferal data that have proven rare at this stratigraphic level. Thick lower Windsor Group evaporites imply a lack of open marine connections, which would necessarily be reflected in the benthic fauna and result in a limited foraminiferal population. These 'reduced' suites are not themselves similar, but they are similarly reduced, as in other apparently better-connected marine basins, e.g., in SW Spain (Cózar, 2003) where the foraminiferal assemblages show many dissimilarities (in diversity, abundance, and first occurrences of taxa) compared with neighboring basins in Morocco, France, and England. In a similar manner, the Maritimes Basin it notable for the rarity of one of the most diagnostic North American taxa, Eoendothyranopsis Reitlinger and Rostovzeva in Reitlinger, 1966, which is widespread in Visean North American successions (e.g., Mamet and Skipp, 1970a, b), but it is also common in Boreal and northwestern Paleotethyan realms (e.g., Loeblich and Tappan, 1987).

Another constraint is that the most diverse and richer realms (both in terms of numbers of genera and species, and also number of specimens) are the Paleotethyan and Boreal realms (Mamet and Skipp, 1970a, 1979; Mamet, 1977; Davydov, 2014) as well as realms with more endemic taxa. Thus in the Maritimes Basin, the absence of more numerous Paleotethyan taxa is more likely for North American affinities. A final constraint is the established migration routes for foraminifers. According to Mamet and Skipp (1970a) and Mamet (1977), most foraminifers are Euroasiatic in origin and migrated westward to western Europe and later to American and Arctic realms. This migration route was established on the basis of: (1) the earliest Late Devonian Endothyridae flourished in Eurasia but are rarely observed in North America; (2) the presence of complete phylogenetic lines in Europe but incomplete ones in North America; (3) impoverished microfauna in North America in regard to Eurasian assemblages, and with few endemic taxa; and (4) heterochronism of the base of the acmes and first occurrences (the oldest forms always occur first in Eurasia, then in the Arctic, and finally in the North American Cordillera). This direction in essence suggests that a communication route had to have existed between western Europe and eastern North America, and those taxa recorded in basins such as the Midcontinent had to have crossed using the Rheic Ocean and then via regions with more similarities with western Europe, i.e., the Maritimes Basin. However, some taxa must have migrated via the northern Boreal Ocean through the Franklinian corridor and Alaska (Harris et al., 1997; Davydov and Cózar, 2019; Fig. 2).

A distinctive feature of the Maritimes Basins, as noted by Mamet (1970) and Jansa and Mamet (1984), is the absence of typical large foraminifers recorded in the Paleotethys realm (e.g., Omphalotis omphalota, large Archaediscus Brady, 1873, Bradyina, Janischewskina Mikhailov, 1939). The absence of these taxa in the Maritimes Basin is significant, but even in betterconnected marine basins in SW Europe, they can show a similar phenomenon. For instance, in Sierra Morena in SW Spain, which should be paleogeographically relatively close to the Maritimes Basin, a typical late Visean-early Serpukhovian succession occurs (Cózar, 2003). Currently, from this succession, more than 4,000 thin sections have been studied, and only one specimen of Bradyina has been recorded, and no more than five specimens of Janischewskina. In addition, only sparse specimens of the large species of Archaediscus have been recorded, and the largest species are absent, compared to successions in Britain and Ireland. Thus, the absence of certain taxa, although at first glance might seem to provide a solid paleogeographic argument, could on the other hand be explained by responses to paleoecological constraints. Hence, the absence of some species is not exclusive to the Maritimes Basin, and needs to be further investigated due to similar patterns in unquestionable Paleotethyan basins. Furthermore, Jansa and Mamet (1984) considered the poor assemblages of the Maritimes Basin as being themselves characteristic and caused by a certain isolation from the main region of marine sedimentation and migration routes.

The second main argument in the comparison of Maritimes Basin foraminifers with those of the North American Realm, is the genus Zellerinella (= Zellerina Mamet in Mamet and Skipp, $1970 \mathrm{~b}$, preoccupied), which was formerly considered endemic to this realm (Mamet, 1974c; Armstrong and Mamet, 1977). Equatorial sections might be confused with Eostaffella Rauzer-Chernousova, 1948 (Rauzer-Chernousova, 1948a), Endostaffella Rozovskaya, 1961, or other similar planispiral genera, but the axial sections are more distinctive. Since these earlier studies, the taxonomy of this taxon has progressed notably, and species originally interpreted as a primitive Millerella Thompson, 1942 by Zeller (1953) (e.g., Millerella tortula Zeller, 1953 and Millerella designata Zeller, 1953) were included in the genus Zellerina/Zellerinella by Mamet in Mamet and Skipp (1970b) and Mamet (1981), and was later reassigned to Paramillerella Thompson, 1951 (Brenckle and Groves, 1981), Plectomillerella Brazhnikova and Vdovenko in Aizenverg et al., 1983 (van Ginkel, 2010), or simply 'Millerella' 
(Gibshman, 2001). The type species of the genus, Endothyra discoidea Girty, 1915, is now considered an Endostaffella (Brenckle, 2005). Independently of the preferred genus name, the same species have been recognized from China (e.g., Groves et al., 2012), eastern Europe (e.g., Gibshman, 2003), western Europe (e.g., Cózar and Somerville, 2016), and northern Africa (Cózar et al., 2011, 2016b). Thus, the genus is now considered as cosmopolitan and it cannot be used to ascribe the foraminiferal fauna of the Maritimes Basin to the North American Realm.

In the faunal list of Mamet (1970), the occurrence of Plectogyranopsis ex gr. P. hirosei (Okimura, 1965) and Haplophragmella Rauzer-Chernousova and Reitlinger in RauzerChernousova et al., 1936 need to be highlighted. The latter is a Paleotethyan taxon, and it is likely that specimens recorded in the Windsor Group might be included in the genus Mstinia Dain in Dain and Grozdilova, 1953. Only Mstinia irregularis (Rauser-Chernousova, 1938) has been documented in the North American craton by Rich (1980). True Haplophragmella seems to be restricted to the former Soviet Union basins, and most specimens (if not all) recorded in western Europe need to be referred to Mstinia/Nevillea Conil and Lys in Conil et al., 1980 (Pille, 2008; Vachard et al., 2010). Plectogyranopsis hirosei is only known from the Paleotethys Realm (eastern and western), except in the Arctic (Mamet et al., 1993). Endothyranella sp. is reinterpreted here as Mikhailovella gracilis (RauserChernousova, 1948 [Rauzer-Chernousova, 1948a]), a typical Paleotethyan taxon, and Mikhailovella sp. of Mamet (1970) is rather similar to the Mikhailovella fresnedosensis Cózar, 2001 recorded at Sierra Morena (Cózar, 2001). In addition, the Maritimes Basin assemblages also contain Omphalotis, Pseudoendothyra Mikhailov, 1939, and Pseudolituotuba Vdovenko, 1971, genera typically represented in the Paleotethyan and Boreal realms.

Koktjubina Marfenkova, 1991 was originally described from Kazakhstan by Marfenkova (1991), and she also included a previously described species from Kazakhstan by Vdovenko (1962), Spiroplectammina exotica Vdovenko, 1962, and a species described from the Windsor Group by Mamet (1970), Biseriammina? windsorensis Mamet, 1970. The genus is predominantly of Paleotethyan affinities, although some rare exceptions are known from the Midcontinent. Rich (1980, pl. 5, fig. 1, non fig. 4) determined Biseriella? exotica (Vdovenko, 1962) in the southern Appalachians, and the specimens identified as Biseriella parva (Chernysheva, 1948) (pl. 5, figs. 2, 3, 6, 7, 10) are also attributable to Koktjubina. Later, Rich (1986, pl. 1, figs. 14-15) identified similar specimens of Biseriella parva as Biseriella exotica. This species, now Koktjubina exotica (Vdovenko, 1962), might be also present in the Peratrovich Formation of southern Alaska (Mamet et al., 1993, pl. 13, fig. 7 only).

Three species of Koktjubina are recorded in Ireland, i.e., Koktjubina? atlantica Cózar and Somerville, 2012, Koktjubina windsorensis (Mamet, 1970), and Koktjubina exotica. The most evolved species, described as Kokjubina? atlantica by Cózar and Somerville (2012), is widespread in Ireland and recorded in the Brigantian of SE Ireland. This species occurs in the Windsor Group (Mamet, 1970, pl. 1, fig. 5, as undetermined Biseriamminidae) and in the Canadian Cordillera (Mamet, 1976, pl. 81, figs. 12, 13, as Biseriella sp.). Koktjubina windsorensis is recorded only in the Benburb area of Northern
Ireland (see location, Mitchell and Mitchell, 1983), where it occurs in the latest Asbian and Brigantian (Cózar and Somerville, 2012). As mentioned above, Koktjubina windsorensis is known throughout the Windsor Group in the Maritimes Basin, where it was identified as a species of Biseriammina Chernysheva, 1941 by Mamet (1970). Its first appearance in the Maritimes Basin in lower Windsor Group strata differs from its most commonly reported occurrences in the late Visean and Serpukhovian (e.g., von Bitter et al., 2007). The third species recorded in Ireland is Koktjubina exotica, which occurs in the Benburb area and in NW Ireland, but as mentioned above, also in the Midcontinent. These three species clearly suggest a faunal interchange between the Maritimes Basin and Ireland, and Koktjubina windsorensis seems to be endemic to the Maritimes Basin and Northern Ireland.

Jansa et al. (1978) and Brisebois (1979) documented, in widely separated portions of the Maritimes Basin, the occurrence of Polysphaerinella bulla Mamet, 1973. Described from Belgium and France (Conil and Lys, 1964; Mamet, 1973), this taxon is a unilocular tuberitinid with secondary spheres (see Vachard, 2016). It is otherwise known only from basins in the western Paleotethys, including Ireland and Britain (e.g., Vachard and Tahiri, 1991; Cózar and Rodríguez, 2000; Pille, 2008).

On the other hand, revision of foraminiferal assemblages previously published by other authors in von Bitter et al. (2007) are typically Paleotethyan in origin. Moreover, it can be concluded from the above-discussed data, that the foraminiferal genera from the Maritimes Basin are typically European and north African (see Table 2). Thus, in summary: (1) there is a single foraminiferal taxon (Eoendothyranopsis) in the Maritimes Basin assemblages that is considered more common in the North American Realm, although it has not been illustrated; (2) there are three typical Paleotethyan foraminiferal species: Plectogyranopsis hirosei, Mikhailovella gracilis, and the unilocular Polysphaerinella bulla, as well as the genera Haplophragmina Reitlinger, 1950, Omphalotis, Pseudoendothyra, and Pseudolituotuba; (3) there is one virtually endemic Paleotethyan genus, Koktjubina, of which one species (Koktjubina windsorensis) is known only from the Maritimes Basin and Northern Ireland; and (4) one other species (Mikhailovella fresnedosensis) is only recorded in the Maritimes Basin and SW Spain.

Another interesting feature of the foraminiferal assemblages of the Maritimes Basin is that they occur at similar stratigraphic levels as in western Europe (von Bitter et al., 2007). It is well-known that the majority of North American taxa originated in the Paleotethys realm, and that they migrated westward. This process of migration is characterized by a delay of $2-3 \mathrm{Myr}$, and even up to $5 \mathrm{Myr}$, before their first appearances in North America, compared to the Paleotethys realm (Mamet, 1977; Davydov, 2014). The apparent absence of these lags in the Maritimes Basin also suggests Paleotethyan affinities for the fauna of the Maritimes Basin.

\section{Other fossil groups}

Conodonts. - The main studies of conodont faunas from the Maritimes Basin are those of Globensky (1967), von Bitter (1976), and von Bitter and Plint-Geberls (1982, 1987), subsequently summarized by von Bitter et al. (2007). Only 


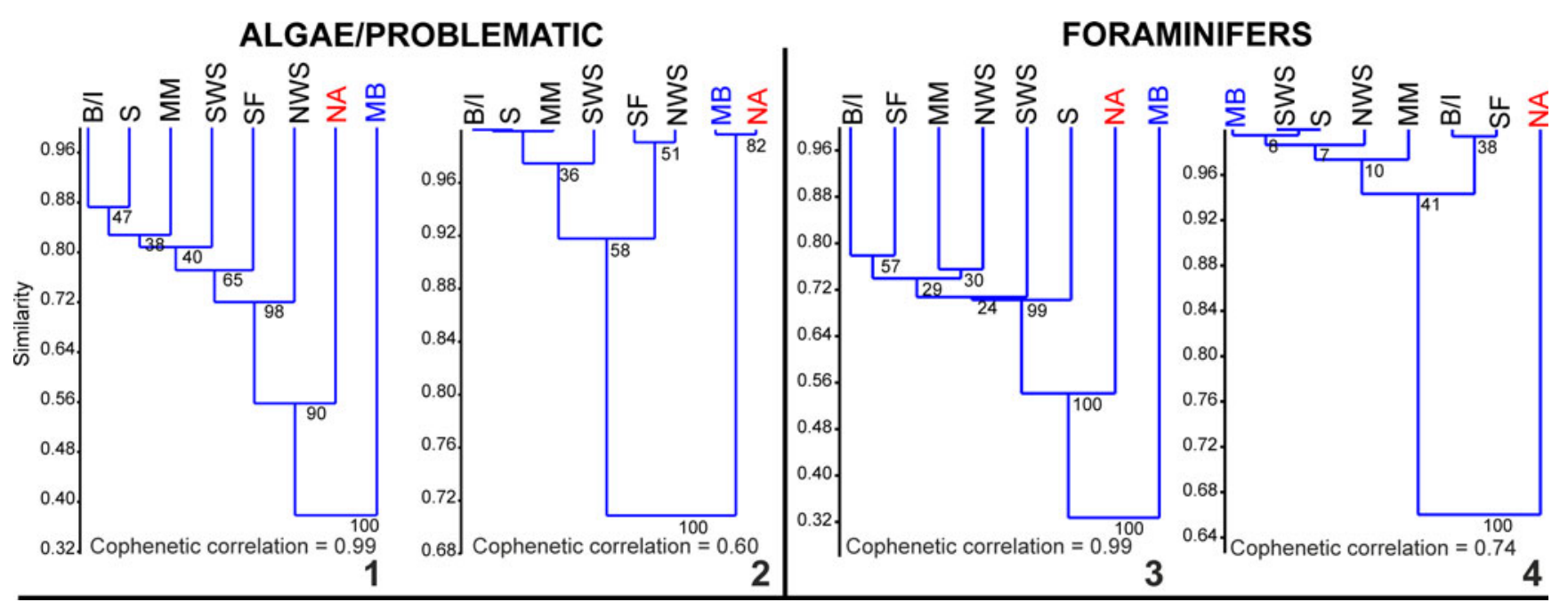

Figure 4. Dendrograms from hierarchical cluster analyses of algae/problematic algae and foraminifers using the Jaccard coefficient $(\mathbf{1}, \mathbf{3})$, and Raup-Crick coefficient $(\mathbf{2}, \mathbf{4})$ by unweighted pair-group average (UPGMA) method (node percentages are bootstrap support with 1,000 iterations). B/I = Britain and Ireland; MB = Maritimes Basin; MM = Moroccan Meseta; NA = North America; NWS = NW Spain; S = Sahara; SF = southern France; SWS = SW Spain .

Globensky (1967) suggested that the conodont assemblages were representative of the North American realm, although following the reinterpretation of some of Globensky's specimens by von Bitter (1976), the assemblage has more recently been considered as Eurasian. This has been corroborated in the biogeographic provinces defined by Higgins (1981), and more recently, it has been recognized that common taxa are shared between the Maritimes Basin and Britain, e.g., Mestognathus Bischoff, 1957, Taphrognathus transatlanticus von Bitter and Austin, 1984, Clydagnathus windsorensis (Globensky, 1967), Vogelgnathus pesaquidi (Purnell and von Bitter, 1992), Vogelgnathus campbelli (Rexroad, 1957), and Vogelgnathus postcampbelli (Austin and Husri, 1974) (von Bitter and Austin, 1984; von Bitter et al., 1986; Purnell and von Bitter, 1992).

Rugose corals.-Since the pioneering work of Lewis (1935), rugose corals from the Maritimes Basin have been traditionally considered paleobiogeographically closer to western European assemblages than to American rugose-coral assemblages (Hill, 1973, 1981). Although taxonomic determinations were not conclusively documented, Poty (2002) recently revised those rugose corals and confirmed that most are typically represented in western Europe, notably in basins from northern England, Ireland, and southern France (Actinocyathus d'Orbigny, 1849, Amplexizaphrentis Vaughan, 1906, Axophyllum Milne-Edwards and Haime, 1850, Koninckophyllum Thomson and Nicholson, 1876, Lonsdaleia McCoy, 1849, Nemistium Smith, 1928, Palastraea McCoy, 1851, and Siphonodendron McCoy, 1849).

Miospores.-Following the study by Clayton (1985), palynologists have widely accepted that Atlantic Canada belongs to the same paleobiogeographic province as Europe. Biostratigraphic zones defined in the Windsor Group and coeval strata (e.g., Utting, 1987; Utting and Giles, 2004) are comparable to those used in western Europe (e.g., Neves et al., 1972, 1973; Clayton et al., 1977). A close comparison of both spore zonal schemes was documented by Utting and Giles (2004), and the European miospore zonal scheme, as well as European regional substages, are now used in biostratigraphic analyses of the region (e.g., Jutras et al., 2001, 2015; von Bitter et al., 2007; Utting and Giles, 2008).

Brachiopods. - Von Bitter and Legrand-Blain (2007) studied the gigantoproductids from the Windsor Group in Nova Scotia, based on specimens they collected themselves and those illustrated by previous authors. They recognized several taxa denominated as typical 'Old World' brachiopods, especially highlighting the occurrence of Latiproductus sp. and Gigantoproductus cf. G. crassiventer (Prentice, 1949), and the close relationship between Nova Scotia and central England.

Trilobites.-Trilobites have not yet been studied in detail in the region, but Brezinski (2003) recorded Paladin eichwaldi (Fischer von Waldheim, 1825) in the Windsor Group, which he interpreted to be a typical European taxon.

\section{Paleobiogeographic results}

The dendrograms resulting from hierarchical cluster analyses of algae/problematic algae and foraminifers using the Jaccard coefficient show a low similarity index for the Maritimes Basin (Fig. 4.1, 4.3). The highest similarity indices obtained with algae (0.44) and foraminifers (0.34), although still low values, suggest a closer position for the Maritimes Basin with the North American craton. However, in the case of foraminifers, the similarity index with SW Spain is also 0.34. This is interpreted as the result of 'missing' or under-represented data in the Maritimes Basin, which gives an artificial coincidence with the poorest North American Realm, or is composed of numerous endemic forms. The dendrograms using the RaupCrick coefficient provide more diverse results. The algal cluster also shows a close position of the Maritimes Basin with North America (Fig. 4.2). In contrast, the foraminiferal cluster shows 


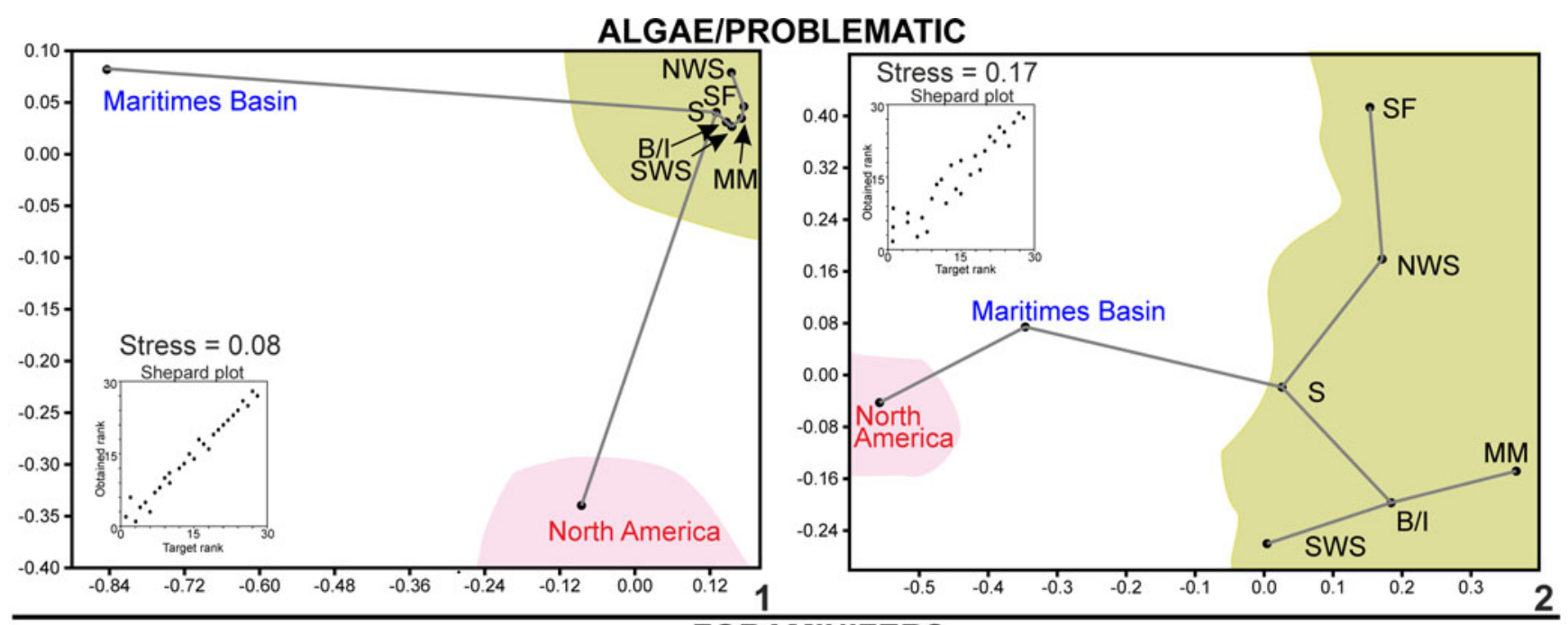

FORAMINIFERS
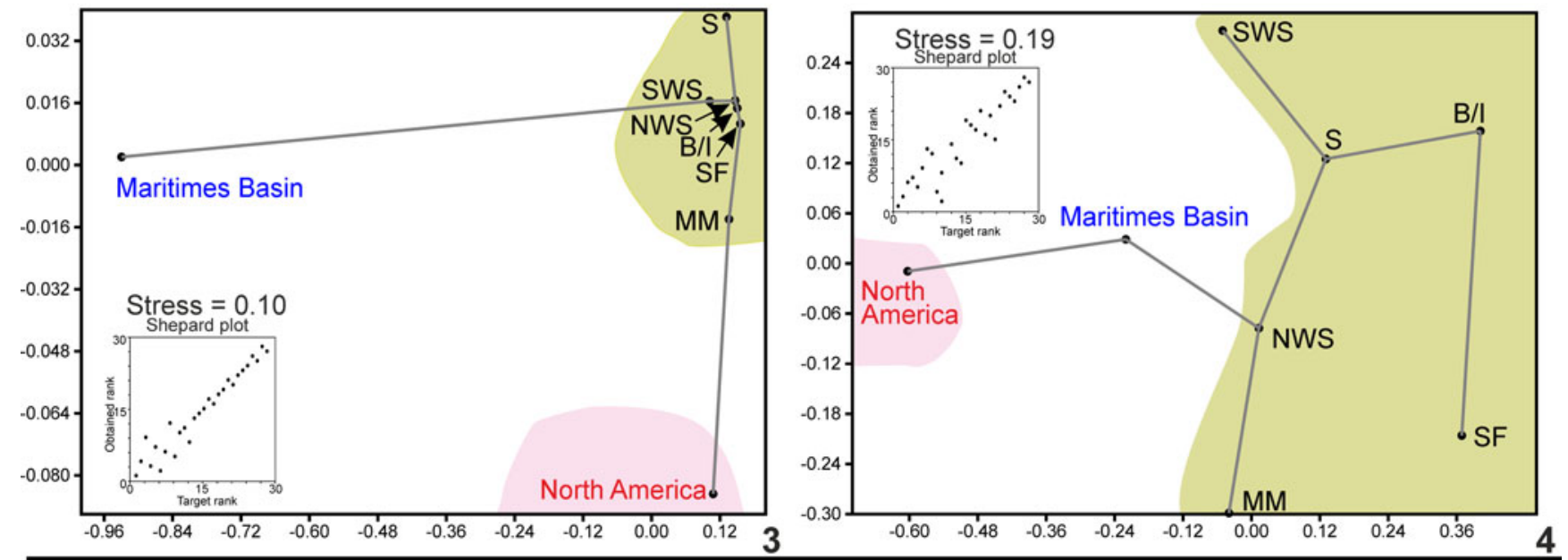

Figure 5. Non-metric Multidimensional Scaling (NMDS) ordination method using the Jaccard coefficient $(\mathbf{1}, \mathbf{3})$ and Raup-Crick coefficient $(\mathbf{2}, \mathbf{4})$ of algae/ problematic algae and foraminifers. Abbreviations as in Fig. 4.

higher similarities with terranes in Spain and Gondwana (Fig. 4.4). It might be possible to explain the apparent 'anomaly' of the algal data in both the Jaccard and Raup-Crick coefficient methods, in which they show closer affinity to North America, as a result of the fewer number of genera (one-third less) in the database compared to the foraminifers.

The ordination methods (NMDS) using the Jaccard coefficient always suggest widely distant positions between the Maritimes Basin and North American and Paleotethyan realms, slightly closer to the Paleotethys realm, specifically, the Gondwana craton (Sahara) (Fig. 5.1). The foraminifers show closer affinities with the northern Variscan Front (Moroccan Meseta and Sierra Morena, SW Spain) (Fig. 5.3).

These affinities are emphasized using the Raup-Crick coefficient, in which the Maritimes Basin is mostly in an intermediate position between North America and western Europe/ northern Africa, which is the most logical presumption. The closer distances, depending on the fossil group, are with the southeastern terranes (NW Spain) and Gondwana (Sahara) (Fig. 5.2, 5.4), but not with Britain/Ireland, as previously authors have proposed.
To minimize this plausible 'absence of data' effect in the Maritimes Basin, both groups were analyzed together, and the biota results show a closer proximity to Gondwana or the southern terranes (Fig. 6), at similar distances than with North America. Secondarily, it is observed that there is a close relationship between the Maritimes Basin and terranes in the northern Variscan Front, e.g., SW Spain. However, a close relationship with Laurussia was not observed, as some particular taxa of foraminifers, conodonts, brachiopods, and miospores have suggested. It must be noted that the analysis for algae has been run also considering only Kulikia and not Pekiskopora, and the results were similar. This confirms that the occurrence of a particular taxon did not exert excessive weight in paleobiogeographic comparisons.

A major concern about the lack of diversity of the Maritimes Basin is seen in the dichotomic results using the Jaccard or Raup-Crick coefficients for individual fossil groups (Figs. 4, 5). The Jaccard coefficient is one of the more widely used coefficients for biogeographic models, but owing to missing data, the Raup-Crick coefficient has become more commonly used in paleobiogeographical models, to highlight 

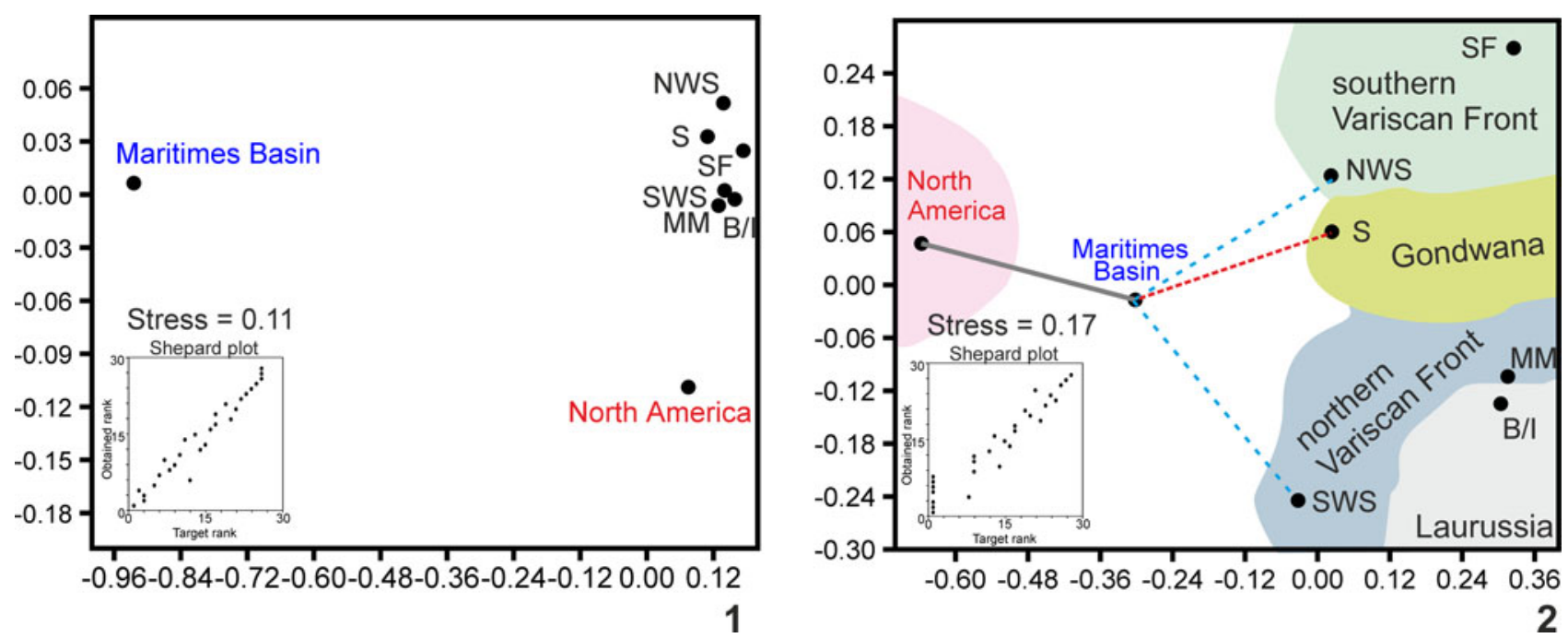

Figure 6. Paleobiogeographical relations of the two fossil groups used in Fig. 5. Non-metric Multidimensional Scaling (NMDS) with the Jaccard coefficient (1) and Raup-Crick coefficient (2). Abbreviations as in Fig. 4.

unusual taxa and not the more widely expanded taxa. This difference between the indices is minimized when the database is larger (Fig. 6), showing similar results.

The lack of diversity is a marked handicap in analysis of the fauna and flora of the Maritimes Basin, because the total number of recorded foraminiferal and algal genera are only one-quarter or one-third as large as those in the Paleotethys Realm (26 vs 107 and 23 vs 70, respectively), and one-half of those in North America (26 vs 53, and 23 vs 42, respectively) (already considered as containing impoverished assemblages; see Tables 1,2) Thus, although low diversity was considered a characteristic feature of the Maritimes Basin by Jansa and Mamet (1984), it is apparent that further research is necessary to increase its recorded diversity, which currently looks insufficient; owing to this apparent low diversity, the statistical results have to be taken with some caution.

\section{Paleobiogeographic implications}

Because the oldest Visean rocks of the Windsor Group succession are dominated by thick evaporites (Fig. 3), Mamet (1970) and Jansa and Mamet (1984) postulated that the Maritimes Basin was a semiclosed platform. This was invoked for the precipitation of evaporites, because most paleogeographic reconstructions show Ireland/Britain and the Maritimes Basin at approximately the same low latitude, between $10^{\circ}$ and $20^{\circ} \mathrm{S}$ (e.g., Roy, 1973; Smith et al., 1973; but not Ziegler, 1978). Jansa and Mamet (1984) considered that the distance between Ireland and the Maritimes Basin was at least $1,000 \mathrm{~km}$, and separated partly by a graben/rift structure (Rockall-Hatton Bank of Le Pichon, 1977 and Ziegler, 1978) and involved a wide Rheic Ocean. Recent reconstructions suggest that this distance was $\sim 800 \mathrm{~km}$ during the Devonian (Waldron et al., 2018). Thus, it can be assumed that the distance during the Mississippian was even less, due to the closing related to the progressing Variscan orogeny.

Despite the faunal, floral, and stratigraphical similarities between the Maritimes Basin and western European/northern African basins, it is certainly apparent that there are also dissimilarities, which prevent a perfect interconnectedness. On the other hand, the tectonic style in the Maritimes Basin is more typically Appalachian, following the assumed attachment of the terranes of the North American region since the Devonian.

The presence of a land barrier between western Europe and Newfoundland was discussed and dismissed by previous authors (e.g., Jansa and Mamet, 1984). We agree with that conclusion, because the existence of a land barrier would have prevented the marine faunal and floral interchange that is now well known. The occurrence of an ocean that acted as a potential paleobiological barrier, controlled by currents, water depth, and ocean width (Jansa and Mamet, 1984), is the most likely hypothesis. However, the presence of this ocean disagrees with the hypothesis that considered that the closure of the Rheic Ocean occurred during the Devonian or in the earliest Mississippian (e.g., Nance et al., 2012) and only a Rhenohercynian Ocean could have been open from the Middle to Late Mississippian (see Fig. 7). The close similarities and clear influence of Paleotethyan late Visean assemblages suggest a narrower ocean than previously supposed, and also, not very deep, to allow migration of most benthic biota. It is difficult to estimate ocean width, but it was likely to have been $<1,000$ $\mathrm{km}$, as recent reconstructions have suggested. Whatever the separation, fluid and constant faunal/floral interchange must have been permitted. However, the low diversity of the Maritimes Basin assemblages is a conditioning factor because it might be the result of the few studies in the region, or it might be actual low diversity. In the first case, if the diversity of assemblages (number of genera) could be increased as a result of more studies in the region, that would imply a more constant interchange of fauna, and thus, a narrower oceanic width. In contrast, if, after more studies in the region, the diversity is not significantly increased, this would imply a certain isolation of the Maritimes Basin, either by a wider ocean or by stronger oceanic currents, allowing only sporadic interchange of fauna/flora with the Paleotethys realm (as during major transgressive events). It is also noteworthy that during sedimentation of the basal Windsor 


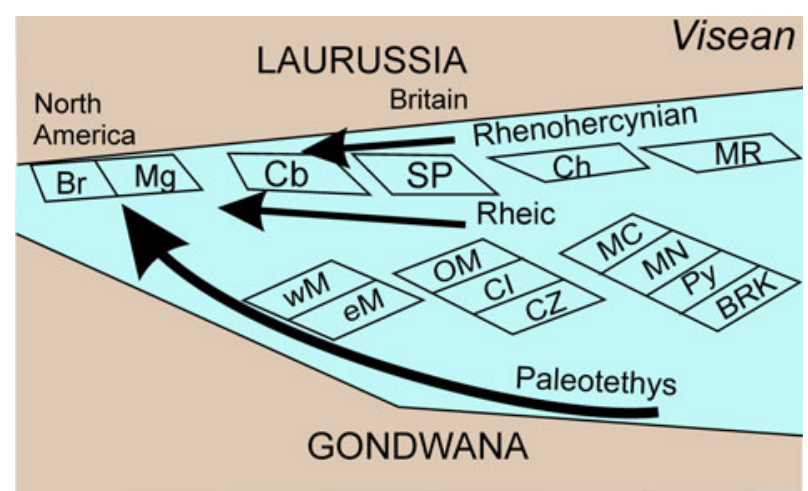

Figure 7. Paleobiogeographical sketch of the Maritimes Basin and basins in western Europe and North Africa during the late Visean-early Serpukhovian. Black arrows are plausible migration routes to the Maritimes Basin. Terranes based on Stampfli et al. (2013). $\mathrm{Br}=$ New Brunswick; BRK= Betics-Rif-Kabbilies; $\mathrm{Cb}=$ Coastal Block; $\mathrm{Ch}=$ Channel; $\mathrm{CI}=$ Central Iberian Zone; $\mathrm{CZ}=$ Cantabrian and Asturian-Leonese Zone; $\mathrm{eM}=$ eastern Moroccan Meseta; $\mathrm{MC}=$ Central Massif of France; $\mathrm{Mg}=$ Meguma; $\mathrm{MN}=$ Montagne Noire; MR = Mid-Germany rise; $\mathrm{OM}=$ Ossa-Morena Zone; $\mathrm{Py}=$ Pyrenees and Catalonia; $\mathrm{SP}=$ South Portuguese Zone; $\mathrm{wM}=$ western Moroccan Meseta.

Group (evaporites of cycle 1, but also in cycles 2-5; Fig. 3), the conditions were distinctly different from those in most of western Europe, i.e., in a restricted basin, with poor communication with the ocean that did not allow a fluid faunal interchange. However, episodes of evaporite precipitation are known in the Mississippian of Ireland, England, Scotland, and Belgium (West et al., 1968; Delmer, 1988; Millward et al., 2018). Nevertheless, the evaporite-rich character of the Windsor Group, likely in part, explains the strongest faunal differences in the lower part of the succession, irrespective of whether it is early Visean or middle Visean.

The resulting data are more controversial, perhaps, in part, arising from the paucity of the eastern Canadian assemblages. The most widely supported hypothesis is that direct communication between the Maritimes Basin and Ireland/Britain is not obviously supported by statistical analyses, but rather suggests a stronger similarity and closer geographic proximity with Gondwana and the terranes in the Variscan Front. This implies that although individual species might imply an artificially closer paleobiogeographic relationship between the Maritimes Basin and Ireland/ Britain, the whole assemblage is more representative of Gondwana. Certainly, lateral migration through the Rheic Ocean platforms is more easily envisaged, and the migration of Albertaporella from the North American Realm to the south of Ireland during the early Visean confirms a still-open Rheic Ocean. During the late Visean-early Serpukhovian, the migration of many similar species of foraminifers, conodonts, rugose corals, and gigantoproductid brachiopods to the Appalachians confirms that that communication still existed.

In some paleogeographic models (e.g., Stampfli et al., 2013), this communication between the Maritimes Basin and Britain could be also possible via the Rhenohercynian Ocean, which was open during the Mississippian (Fig. 7). A rather similar position of the terranes and continents can be observed in the reconstructions by Blakey (2008, fig. 10C), with the Sahara and the Reguibat promontory in front of the Maritimes Basin, although in this reconstruction the Rhenohercynian Ocean was not connected. Tectonic and sedimentological models promote comparison of the Maritimes Basin with those in Ireland and Britain (e.g., Waldron et al., 2018), and it is automatically assumed that the biological influence of those northern regions is inherited. However, alternative scenarios might need to be considered in which the benthic biota arrived in the Maritimes Basin by crossing the Paleotethys Ocean from more southerly positions near the Gondwana coast, or from the northwestern terranes across a still-open Rheic Ocean (Fig. 7). This would suggest narrower oceans in this region for the late Visean-early Serpukhovian period. Indirectly, for this communication with the Paleotethys Ocean to occur, it is envisaged that the Moroccan Meseta was not attached to Gondwana during the Visean (Fig. 6), a fact described only for the early to mid-Visean (Cózar et al., 2020), whereas for the late Visean-early Serpukhovian interval, it is not yet clearly defined. However, if the Meseta was attached to Gondwana, this would imply higher similarity indices between the Meseta and the Maritimes Basin than with Gondwana, which is not the case. The occurrence of Saharan assemblages in the Maritimes Basin suggests that the annexation of the Moroccan Meseta to Gondwana had not happened during the late Visean and early Serpukhovian.

Paleobiogeographic models are, in general, in disagreement with the paleogeographic models based on tectonics, magmatism, or paleomagnetism. For the last, there is a predominance of models that suggest that the closure of the Rheic Ocean occurred during the Devonian, with no connection between the Rheic and Paleotethys oceans (e.g., Kroner and von Romer, 2013; Stampfli et al., 2013; Scotese, 2015), whereas another group of authors considered that the gateway between the two oceans existed until the Permian (Vai, 2003; Walsh et al., 2007; Domeier et al., 2012). Rarely, some authors have highlighted the importance of fossil groups for these paleogeographic reconstructions for the Carboniferous (e.g., Cocks and Torsvik, 2011). Related to this aspect, ammonoids, rugose corals, brachiopods, and foraminifers do not show synchronicity in the timing of the closure of the Rheic-Paleotethys gateway, ranging from the mid-Visean, late Visean, early Serpukhovian, and late Serpukhovian, respectively, but clearly, all are later than the Devonian (Korn et al., 2012; Aretz et al., 2013; Quiao and Shen, 2014, 2015; Davydov and Cózar, 2019). The fauna and flora of the upper cycles of the Maritimes Basin (cycles 2-5), with strong similarities with the Paleotethys realm, confirm good communication at least until the early Serpukhovian (or a younger age for the Windsor-Codroy groups; von Bitter et al., 2007). Anomalous impoverished Visean assemblages in the Maritimes Basin suggest at least intermittent communication with the North America Realm during the same period. Species in common between the Paleotethyan and the North American realms during the Visean/Serpukhovian confirm communication through the Maritimes Basin. Marine communication of the Paleotethys and North American realms through the Maritimes Basin ceased very near the beginning of the Serpukhovian with the termination of any open marine deposition that might have supported even impoverished marine faunas. This stratigraphic break is marked by the top of the Windsor and Codroy groups, assigned a latest Visean to earliest Serpukhovian age by von Bitter et al. (2007). In the Maritimes Basin, miospores recorded a major paleoenvironmental crisis in the Arnsbergian 
(late Serpukhovian) (Utting, 1987; Utting and Giles, 2008; Jutras et al., 2015), a period associated with glacial episodes, shifts in carbon and oxygen isotopic data, and a global-scale late Paleozoic sea-level fall (Isbell et al., 2003; Grossman et al., 2008; Haq and Schutter, 2008; Mory et al., 2008; Gulbranson et al., 2010; Stephenson et al., 2010; Barham et al., 2012; Giles, 2012; Davydov, 2014). These facts coincide with the ultimate closure of the Rheic-Paleotethys gateway, and thus, the formation of the so-called Alleghenian Isthmus, interpreted to have occurred during the late Serpukhovian (Davydov and Cózar, 2019). Before the early Serpukhovian cessation of marine communication, and well before the onset of severe and extensive glaciations of the Pennsylvanian during the coldest times of the Paleozoic (Giles, 2012), marine connections through the Maritimes Basin were at best intermittent and shortlived (Giles, 2009) and limited to short episodes of glacioeustatic marine transgression. Until marine communication ceased, the biota of the Maritimes Basin reflects multiple sources with intermittent linkages to all of our studied regions.

\section{Conclusions}

Analyzing the foraminiferal taxa in the Maritimes Basin, several genera and species typically represented in the Paleotethys realm can be recognized, contrasting with previous studies that the Maritimes Basin lacked typical Paleotethyan genera and species. Typical North American fauna/flora are negligible or absent, and apparent similarities are based on the absence of typical Paleotethyan genera and species. Low diversity has been argued by some as a feature typical of the Maritimes Basin, although it could be simply a result of less-detailed paleontological works or the predominance of hostile facies.

The Maritimes Basin has been compared with basins in Laurussia, in particular Ireland and England. The influence of the Laurussian margin is supported by the occurrence of some species of brachiopods, miospores, and foraminifers, with dispersal via the Rhenohercynian Ocean. However, multivariate analysis of the marine benthic microfossils confirms that although the assemblages are of Paleotethyan affinities, they are closer to assemblages in the Gondwana platform and terranes of the Variscan Front (Moroccan Meseta/SW Spain). Owing to the relative position of the terranes between the Laurussia and Gondwana continents, we suggest that migration of the biota occurred not only via the incipient Paleotethys Ocean, but also by a still-open Rheic Ocean, with additional influence of the Rhenohercynian Ocean. Our assessment indicates multiple sources for the biota of the Maritimes Basin. Paleogeographic models that located the Maritimes Basin opposite the North African coast would fit better in the observed paleobiogeographic relationships.

\section{Acknowledgments}

We would like to thank M. Aretz and an anonymous reviewer for their constructive comments. The research was funded by the Spanish Ministry of Ciencia, Innovación y Universidades (project CGL2016-78738BTE). We acknowledge support of the publication fee by the CSIC Open Access Publication Support Initiative through its Unit of Information Resources for Research (URICI).

\section{References}

Aizenverg, D.E., Astakhova, T.V., Berchenko, O.I., Brazhnikova, N.E., Vdovenko, M.V., Dunaeva, N.N., Zernetskaya, N.V., Poletaev, V.I., and Sergeeva, M.T., 1983, [Late Serpukhovian Substage in the Donets Basin: Kiev, Akademiya Nauk Ukrainskoi SSR, Institut Geologicheskikh Nauk, 164 p. [in Russian]

Antropov, I.A., 1967, [Algae from the Devonian and early Carboniferous (Tournaisian) of the centre of the eastern part of the Russian Platform]: Akademiya Nauk SSSR, Akademiya Nauk SSSR, Sibirskoe Otdelenie, Trudy Instituta Geologii i Geofiziki, p. 118-125. [in Russian]

Aretz, M., Dera, G., Lefebvre, V., Donnadieu, Y., Godderis, Y., Macouin, M., and Nardin, E., 2013, The spatial and temporal distribution of Mississippian rugose corals: Contribution of modelled oceanic currents and temperature data to this problem, in Nardin, E., and Aretz, M., eds., Pre-Cenozoic Climates International Workshop: When Data and Modelling Meet: Strata, sér. 1 , v. 14 , p. $8,9$.

Armstrong, A.K., and Mamet, B.L., 1974, Carboniferous biostratigraphy, Prudhoe Bay State 1 to Northeastem Brooks Range, Arctic Alaska: Bulletin of the American Association of Petroleum Geologists, v. 58, p. 646-660.

Armstrong, A.K., and Mamet, B.L., 1977, Carboniferous microfacies, microfossils, and corals, Lisburne Group, Arctic Alaska: U.S. Geological Survey Professional Paper, v. 849, 144 p.

Armstrong, A.K., Mamet, B.L., and Repetski, J.E., 1992, Stratigraphy of the Mississippian System, south-central Colorado and north-central New Mexico: U.S. Geological Survey Bulletin, v. 1787-EE, 23 p.

Austin, R.L., and Husri, S., 1974, Dinantian conodont faunas of County Clare, County Limerick and County Leitrim: An appendix, in Bouckaert, J., and Streel, M., eds., International Symposium on Belgian Micropalaeontological Limits from Emsian to Viséan, Namur 1974, Volume 3: Brussels, Geological Survey of Belgium, p. 18-69.

Barham, M., Murray, J., Joachimski, M.M., and Williams, D.M., 2012, The onset of the Permo-Carboniferous glaciation: Reconciling global stratigraphic evidence with biogenic apatite $\delta^{18} \mathrm{O}$ records in the late Visean: Journal of the Geological Society of London, v. 169, p. 119-122, https://doi.org/ 10.1144/0016-76492011-102.

Belt, E.S., 1929, Horton-Windsor District, Nova Scotia: Geological Survey Canada, Memoir 155, $268 \mathrm{p}$.

Belt, E.S., 1944, Carboniferous rocks and fossil floras of northern Nova Scotia: Geological Survey Canada, Memoir 238, 277 p.

Belt, E.S., 1969, Newfoundland Carboniferous stratigraphy and its relation to the Maritimes and Ireland: American Association of Petroleum Geologists Memoir, v. 12, p. 734-753.

Bensaid, M., Termier, H., Termier, G., and Vachard, D., 1979, Le Carbonifère (Viséen supérieur-Bachkirien) entre Bou Chber et Ich ou Mellal (Maroc central): Annales de la Société Géologique du Nord, v. 98 (for 1978), p. 189-204.

Bichoff, G., 1957, Die Conodontenstratigraphie des rhenoherzynischen Unterkarbons mit Berucksichtigung der Wocklumeriastufe und der Devon/ Karbon-Grenze: Abhandlungen des Hessischen Landesantes für Bodenforschung, v. 19, p. 1-64.

Blakey, R.C., 2008, Gondwana paleogeography from assembly to breakup-A 500 m.y. odyssey, in Fielding, C.R., Frank, T.D., and Isbell, J.L., eds., Resolving the Late Paleozoic Ice Age in Time and Space: The Geological Society of America Special Paper 441, p. 1-28, https://doi.org/10.1130/2008.2441(01).

Blakey, R.C., 2013, Using paleogeographic maps to portray Phanerozoic geologic and paleotectonic history of western North America [abs.]: AAPG Bulletin, v. 97, p. 146.

Bogush, O.I., 1987, [Systematic features and scope of the genus Globoendothyra Reitlinger, 1959 (Foraminiferida)]: Institut Geologii i Geofiziki, Akademiya Nauk SSSR, Sibirskoe Otdelenie, v. 651, p. 71-95. [in Russian]

Bogush, O.I., and Juferev, O.V., 1962, [Foraminifera and Stratigraphy of Karatau and Talas Alatau Carboniferous Deposits]: Moscow, Akademiya Nauk SSSR, Sibirskoe Otdelenie, Trudy Instituta Geologii i Geofiziki, 234 p. [in Russian]

Bourque, P.-A., Madi, A., and Mamet, B.L., 1995, Waulsortian-type bioherm development and response to sea-level fluctuations: Upper Visean of Béchar Basin, western Algeria: Journal of Sedimentary Research, v. B65, p. 80-95.

Brady, H.B., 1873, On Archaediscus karreri, a new type of Carboniferous Foraminifera: Annals and Magazine of Natural History, v. 12, p. 286-290.

Brazhnikova, N.E., and Vdovenko, M.V., 1973, [Early Visean Foraminifers from Ukraine]: Kiev, Naukova Dumka, 296 p. [in Russian]

Brazhnikova, N.E., and Yartseva, M.V., 1956, [To the question of evolution of the genus Monotaxis]: Academy of Sciences USSR Questions of Micropaleontology, v. 1, p. 62-68. [in Russian]

Brenckle, P.L., 1985, Cribrokamaena and Crassikamaena, new genera of late Paleozoic algae from the United States: Micropaleontology, v. 31, p. 55-67.

Brenckle, P.L., 2004, Late Visean (Mississippian) calcareous microfossils from the Tarim Basin of western China: Journal of Foraminiferal Research, v. 34, p. 144-164, https://doi.org/10.2113/0340144. 
Brenckle, P.L., 2005, A compendium of Upper Devonian-Carboniferous type foraminifers from the former Soviet Union: Cushman Foundation for Foraminiferal Research, Special Publication 38, 153 p.

Brenckle, P.L., and Groves, J.R., 1981, Evolution of eostaffellid foraminifers in late Chesterian (Late Mississippian) strata of the North America Midcontinent: Cincinnati Meeting, Geological Survey of America Bulletin, Abstracts with Programs, v. 13, p. 416.

Brenckle, P.L., and Groves, J.R., 1987, Calcareous foraminifers from the Humboldt Oolite of Iowa: Key to early Osagean (Mississippian) correlations between eastern and western North America: Palaios, v. 1, p. 561-581.

Brenckle, P.L., Marshall, F.C., Waller, S.F., and Wilhelm, M.M.H., 1982, Calcareous microfossils from the Mississippian Keokuk Limestone and adjacent formations, upper Mississippi River Valley: Their meaning for North American and intercontinental corre1ation: Geologica et Paleontologica, v. 15, p. $47-88$.

Brenckle, P.L., Ramsbottom, W.H., and Marchant, T.R., 1987, Taxonomy and classification of Carboniferous archaediscacean foraminifers: Courier Forschungsinstitut Senckenberg, v. 98, p. 11-24.

Brezinski, D.K., 2003, Evolutionary and biogeographical implications of phylogenetic analysis of the late Palaeozoic trilobite Paladin: Special Papers in Palaeontology, v. 70, p. 363-375.

Brisebois, D., 1979, Stratigraphie du Permo-Carbonifère des îles de la Madeleine [Ph.D. thesis]: Montréal, Canada, Université de Montréal, 274 p.

Brisebois, D., and Mamet, B., 1974, Sur la presence des couches de passage du Viséan au Namurian dans les îsles de la Madeleine: Compte-rendu Ssommaire de la Société Géologique de France, v. 1974, p. 60-62.

Browne, R.G., and Pohl, E.R, 1973, Stratigraphy and genera of calcareous Foraminifera of the Fraileys facies (Mississippian) of central Kentucky: Bulletins of American Paleontology, v. 64, p. 169-244.

Bykova, E.V., 1952, [Devonian Foraminifera from Russian Platform and PreUrals]: Trudy Vsesoyuznogo Nauchno-Issledovatel'skogo Geologorazvedochnogo Instituta, v. 60, Microfauna USSR 5, p. 5-64. [in Russian]

Bykova, E.V., 1955, [Devonian Foraminifera and Radiolaria of the Volga-Ural district and central Devonian field, and their significance for stratigraphy]: Trudy Vsesoyuznogo Neftyanogo Nauchno-Issledovatel'skogo Geologorazvedochnogo lnstituta (VNIGRI), n. ser., v. 87, p. 5-190. [in Russian]

Chernysheva, N.E., 1941, [A new genus of Foraminifera from Tournaisian deposits of the Urals]: Reports of the Academy of Sciences USSR, v. 32, p. 69-70. [in Russian]

Chernysheva, N.E., 1948, [Some new species of Foraminifera from the Visean stage of the Makarov district (South Ural)]: Akademya Nauk SSSR Trudy Instituta Geologicheskikh Nauk, v. 62, Geologicheskaya Seriya 19 , p. 246-250. [in Russian]

Clayton, G., 1985, Dinantian miospores and intercontinental correlation, in Escobedo, J.L, Granados, L.F., Meléndez, B., Pignatelli, R., Rey, R., and Wagner, H., eds., Congrès International de Stratigraphie et de Géologie du Carbonifère, 10th, Madrid 1983, Compte Rendu 4: Madrid, Instituto Geológico y Minero, p. 9-23.

Clayton, G., Coquel, R., Doubinger, J., Gueinn, K.J., Loboziak, S., Owens, B., and Streel, M., 1977, Carboniferous miospores of western Europe: Illustration and zonation: Mededelingen Rijks Geologische Dienst, v. 29, p. 1-71.

Cocks, L.M., and Torsvik, T.H., 2011, The Palaeozoic geography of Laurentia and western Laurussia: A stable craton with mobile margins: Earth-Science Reviews, v. 106, nos. 1, 2, p. 1-51, https://doi.org/10.1016/j.earscirev.2011. 01.007.

Conil, R., 1977, Contribution à l'étude des foraminifères du Dinantien de l'Irlande: Annales de la Société Géologique de Belgique, v. 99 (for 1976), p. $467-479$.

Conil, R., and Lys, M., 1964, Matériaux pour l'étude micropaléontologique du Dinantien de la Belgique et de la France (Avesnois), Partie 2, Foraminifères: Mémoires de l'Institut de Géologie de l'Université de Louvain, v. 23, p. $1-$ 296.

Conil, R., and Pirlet, H., 1970, Le calcaire carbonifère du synclinorium de Dinant et le sommet du Famennien: Congrès et Colloques de l'Université de Liège, v. 55, p. 47-63.

Conil, R., Longerstaey, P.J., and Ramsbottom, W.H.C., 1980, Matériaux pour l'étude micropaléontologique du Dinantien de Grande-Bretagne: Mémoires de l'Institut Géologique de l'Université de Louvain, v. 30 (for 1979), p. 5186.

Cózar, P., 2001, Two new late Visean (Mississippian) species of the genera Nevillea and Mikhailovella (Foraminiferida) from the Guadiato Area (SW Spain): Coloquios de Paleontolgía, v. 52, p. 3-11.

Cózar, P., 2003, Foraminiferal fauna and zonation from the early Carboniferous of Guadiato Area (SW Spain): Comparison with European and North African foraminiferal zonal schemes and its palaeobiogeographical implications, in Ahr, W.M., Harris, P.M., Morgan, W.A., and Somerville, I.D., eds., Permo-Carboniferous Carbonate Platforms and Reefs, Society for Economic Paleontologists and Mineralogists Special Publication 78 and American Association of Petroleum Geologists Memoir 83, p. 155-169.
Cózar, P., and Mamet, B.L., 2001, Planohowchinia (Lasiodiscidae, Foraminiferida), a new late Viséan genus, southwestern Spain: Journal of Foraminiferal Research, v. 31, p. 228-232, https://doi.org/10.2113/31.3.228.

Cózar, P., and Rodríguez, S., 2000, 'Microproblematica' del Carbonífero inferior del Área del Guadiato (suroeste de España): Revista Española de Paleontología, v. 15 , p. 9-16.

Cózar, P., and Somerville, I.D., 2005a, Stratigraphy of upper Viséan carbonate platform rocks in the Carlow area, southeast Ireland: Geological Journal, v. 40, p. 35-64, https://doi.org/10.1002/gj. 984 .

Cózar, P., and Somerville, I.D., 2005b, A new species of Mississippian Diploporaceae alga in southeastern Ireland and its palaeobiogeographical significance: Revista Española de Micropaleontología, v. 37, p. 419-430.

Cózar, P., and Somerville, I.D., 2012, Mississippian Biseriamminaceae and their evolutionary development: Journal of Foraminiferal Research, v. 42, p. 216-233, https://doi.org/10.2113/gsjfr.42.3.216.

Cózar, P., and Somerville, I.D., 2016, Problems correlating the late BrigantianArnsbergian western European substages within northern England: Geological Journal, v. 51, p. 817-840, https://doi.org/10.1002/gj.2700.

Cózar, P., and Vachard, D., 2001, Dainellinae subfam. nov. (Foraminiferida du Carbonifère inférieur), révision et nouveaux taxons: Geobios, v. 34, p. 505526, https://doi.org/10.1016/S0016-6995(01)80066-8.

Cózar, P., and Vachard, D., 2003, Neoprincipia nov. gen., a new Mississippian red alga, and remarks on the Archaeolithophyllaceae (Rhodophyta): Geobios, v. 36, p. 505-517, https://doi.org/10.1016/S0016-6995(03)00060-3.

Cózar, P., and Vachard, D., 2004, A new Mississippian dasyclad alga (Chlorophyta) from SW Spain: Implications for the reproductive evolution of the dasyclads during the late Paleozoic: Eclogae Geologicae Helvetiae, v. 97, p. 175-181, https://doi.org/10.1007/s00015-004-1127-4.

Cózar, P., and Vachard, D., 2005, Comparaison d'Hortonella (algue rouge du Carbonifère) avec une structure algaire problématique (racine?): Lysvaella: Revue de Paléobiologie, v. 24, p. 243-249.

Cózar, P., and Vachard, D., 2006, A new Mississippian red alga from southwestern Spain: Geobios, v. 39, p. 791-803, https://doi.org/10.1016/j.geobios.2005.09.002.

Cózar, P., Somerville, I.D., Rodríguez, S., and Medina-Varea, P., 2007, New genera of late Viséan metaspondil dasycladales from the Fuenteobejuna section (Mississippian of the Guadiato Valley, southwestern Spain): Neues Jahrbuch für Mineralogie, Geologie, und Paläontologie, Abhandlungen, v. 246, p. 97-109, https://doi.org/10.1127/0077-7749/2007/0246-0097.

Cózar, P., Somerville, I.D., and Burgess, I., 2008, New foraminifers in the Visean/Serpukhovian boundary interval of the Lower Limestone Formation, Midland Valley, Scotland: Journal of Paleontology, v. 82, p. 906-923, https://doi.org/10.1666/07-103.1.

Cózar, P., Vachard, D., Somerville I.D., Pille L., and Medina-Varea, P., 2009, Revision and new species of the late Palaeozoic dasyclad algae Windsoporella and Eovelebitella: Palaeontographica B, Palaeobotany-Palaeophytology, v. 282, p. 39-67, https://doi.org/10.1127/palb/282/2009/39.

Cózar, P., Said, I., Somerville, I.D., Vachard, D., Medina-Varea, P., Rodríguez, S., and Berkhli, M., 2011, Potential foraminiferal markers for the ViséanSerpukhovian and Serpukhovian-Bashkirian boundaries-A case-study from central Morocco: Journal of Paleontology, v. 85, p. 1005-1127, https://doi.org/10.1666/10-158.1.

Cózar, P., García-Frank, A., Somerville, I.D., Vachard, D., Rodríguez, S., Medina-Varea, P., and Said, I., 2014, Lithofacies and biostratigraphical correlation of marine Carboniferous rocks in the Tindouf Basin, NW Africa: Facies, v. 60, p. 941-962, https://doi.org/10.1007/s10347-014-0409-1.

Cózar, P., Sanz-López, J., and Blanco-Ferrera, S., 2015, Late ViséanSerpukhovian lasiodiscid foraminifers in Vegas de Sotres section (Cantabrian Mountains, NW Spain): Potential biostratigraphic markers for the Viséan-Serpukhovian boundary: Geobios, v. 48, p. 213-238, https://doi. org/10.1016/j.geobios.2015.02.006.

Cózar, P., Somerville, I.D., Sanz-López, J., and Blanco-Ferrera, S., 2016a, Foraminiferal biostratigraphy across the Visean/Serpukhovian boundary in the Vegas de Sotres section (Cantabrian Mountains, Spain): Journal of Foraminiferal Research, v. 46, p. 171-192, https://doi.org/10.2113/gsjfr.46.2.171.

Cózar, P., Somerville, I.D., Vachard, D., Coronado, I., García-Frank, A., Medina-Varea, P., Said, I., del Moral, B., and Rodríguez, S., 2016b, Upper Mississippian to lower Pennsylvanian biostratigraphic correlation of the Sahara Platform successions on the northern margin of Gondwana (Morocco, Algeria, Libya): Gondwana Research, v. 36, p. 459-472, https://doi.org/10.1016/j.gr.2015.07.019.

Cózar, P., Somerville, I.D., Blanco-Ferrera, S., and Sanz-López, J., 2018, Palaeobiogeographic context in the development of shallow-water late Viséan-early Bashkirian benthic foraminifers and calcareous algae in the Cantabrian Mountains (Spain): Palaeogeography, Palaeoclimatology, Palaeoecology, v. 511, p. 620-638, https://doi.org/10.1016/j.palaeo.2018. 09.031 .

Cózar, P., Vachard, D., Izart, A., Said, I., Somerville, I.D., Rodríguez, S., Coronado, I., El Houicha, M., and Ouarhache, D., 2020, Lower-middle 
Viséan transgressive carbonates in Morocco: Palaeobiogeographic insights: Journal of African Earth Sciences, v. 168, p. 103850, https://doi.org/10. 1016/j.jafrearsci.2020.103850.

Cummings, R.H., 1955a, New genera of Foraminifera from the British lower Carboniferous: Journal of the Washington Academy of Sciences, v. 45, p. $1-8$.

Cummings, R.H., 1955b, Stacheoides, a new foraminiferal genus from the British upper Paleozoic: Journal of the Washington Academy of Sciences, v. 45, p. 342-346.

Cushman, J.A., 1927, An outline of a reclassification of the Foraminifera: Contributions from the Cushman Laboratory for Foraminiferal Research, v. 3, no. 1 , p. 1-105.

Cushman, J.A., 1928, Additional genera of Foraminifera: Contributions from the Cushman Laboratory for Foraminiferal Research, v. 4, p. 1-8.

Cushman, J.A., and Waters, J.A., 1928, Some Foraminifera from the Pennsylvanian and Permian of Texas: Contributions from the Cushman Laboratory for Foraminiferal Research, v. 4, no. 2, p. 31-55.

Dain, L.G., and Grozdilova, L., 1953, [Fossil Foraminifera of the USSR: Tournayellidae and Archaediscidae]: Proceedings of the Oil Research Geological Institut (VNIGRI), v. 74, p. 1-115. [in Russian]

Davydov, V.I., 2014, Warm water benthic Foraminifera document the Pennsylvanian-Permian warming and cooling events-The record from the western Pangea tropical shelves: Palaeogeography, Palaeoclimatology, Palaeogeog raphy, v. 414, p. 284-295, https://doi.org/10.1016/j.palaeo.2014.09.013.

Davydov, V.I., and Cózar, P., 2019, Did closure of the Rheic-Tethys oceanic gateway trigger of the onset of the Bashkirian Glaciation? Constraints from the warm-water benthic Foraminifera: Palaeogeography, Palaeoclimatology, Palaeoecology, v. 531, p. 108403.

Delmer, A., 1988, Le sondage de Saint-Ghislain (pl. 150E, no. 387): Stratigraphie et tectonique en terrain houiller. Sa liaison avec le sondage de Jeumont I: Annales de la Société Géologique de Belgique, Special Volume Deep Seismics and Drillings, v. 111, p. 291-295.

Devera, J.A., 1987, Asphaltinoides incertae sedis, a new genus from the Devonian of Illinois: Journal of Paleontology, v. 61, p. 1274-1278.

Domeier, M., Torsvik, T.H., and van der Voo, R., 2012, The Paleogeography of Pangea: Progress and Problems: Espoo, Geological Survey of Finland, 34 p.

Ehrenberg, C.G., 1854, Mikrogeologie: Das Erden und Felsen Schaffende Wirken des Unsichtbar Kleinen Selbstständigen Lebens auf der Erde: Leipzig, Germany, Leopold Voss, 374 p.

Eickhoff, G., 1968, Neue Textularien (Foraminifera) aus dem Waldecker Unterkarbon: Paläontologische Zeitschrift, v. 42, p. 162-178.

Elliott, G.F., 1970, Calcareous algae new to the British Carboniferous: Palaeontology, v. 13, p. 443-450.

Etheridge, R., 1873, Explanation of Sheet 23: Lanarkshire: Central Districts: Memoirs of the Geological Survey of Great Britain (Scotland) (Sheet), Edinburg, $114 \mathrm{p}$.

Fischer von Walddheim, G., 1825, Trilobiten, 54, in Eichwalds, E., Geognostico-zoologicae per Ingriam Marisque Baltici Provincial nec non de Trilobitis Observations: Kasan, Russia, 58 p.

Gallagher, S.J., 1996, The stratigraphy and cyclicity of the late Dinantian platform carbonates in parts of southern and western Ireland, in Strogen, P., Somerville, I.D., and Jones, G.L., eds., Recent Advances in Lower Carboniferous Geology: Geological Society London, Special Publication 107, p. 239-251.

Gallagher, S.J., and Somerville I.D., 1997, Late Dinantian (lower Carboniferous) platform carbonate stratigraphy of the Buttevant area North Co. Cork, Ireland: Geological Journal, v. 32, p. 313-335.

Galloway, J.J., and Ryniker, C., 1930, Foraminifera from the Atoka Formation of Oklahoma: Oklahoma Geological Survey, Circulars, v. 21, p. 1-36.

Ganelina, R.A., 1956, [Foraminifera of the Visean deposits of the northwest region of the lower Moscow basin]: Mikrofauna SSSR, Trudy Vsesoyuznogo Nauchno-Issledovatel'skogo Geologorazvedochnogo Instituta, v. 98, no. 8, p. 61-159. [in Russian]

Garwood, E.J., 1914, Some new rock-building organisms from the lower Carboniferous beds of Westmorland: Geological Magazine, v. 51, p. 265-271

Gibling, M.R., Culshaw, N., Pascucci, V., Waldron, J.W.F., and Rygel, M.C. 2019, The Maritimes Basin of Atlantic Canada: Basin creation and destruction during the Paleozoic assembly of Pangea, in Miall A., ed., The Sedimentary Basins of the United States and Canada: Amsterdam, Elsevier, p. 267-314.

Gibshman, N.B., 2001, Foraminiferal biostratigraphy of the Serpukhovian Stage stratotype (Zaborie Quarry, Moscow Basin): Newsletter on Carboniferous Stratigraphy, v. 19, p. 31-34.

Gibshman, N.B., 2003, Foraminifers from the Serpukhovian Stage stratotype, the Zabor'e Quarry (Moscow Region): Stratigraphy and Geological Correlation, v. 11, p. 39-63.

Giles, P.S., 1981, Major transgressive-regressive cycles in middle to late Visean rocks of Nova Scotia: Nova Scotia Department of Mines and Energy, Paper $81-2$, p. $1-27$.
Giles, P.S., 2009, Orbital forcing and Mississippian sea level change: Time series analysis of marine flooding events in the Viséan Windsor Group of eastern Canada and implications for Gondwana glaciation: Bulletin of Canadian Petroleum Geology, v. 57, p. 449-470, https://doi.org/10.2113/gscpgbull. 57.4.449.

Giles, P.S., 2012, Low-latitude Ordovician to Triassic brachiopod habitat temperature (BHTs) determined from $\delta_{[\text {brachiopod calcite] }}^{18}$ A cold hard look at ice-house tropical oceans: Palaeogeography, Palaeoclimatology, Palaeoecology, v. 317/318, p. 134-152, https://doi.org/10.1016/j.palaeo.2012. 01.002 .

Girty, G.H., 1915, The fauna of the Batesville sandstone in northern Arkansas: Bulletin of the U.S. Geological Survey, v. 593, p. 1-170.

Globensky, Y., 1967, Middle and Upper Mississippian conodonts from the Windsor Group of the Atlantic provinces of Canada: Journal of Paleontology, v. 41, p. 432-448.

Golubtsov, V.K., 1961, [Kulikia, new genus of calcareous algae in the Viséan stage]: Minsk Izdateltsvo, Akademiya Nauk Beloruss SSR, v. 3, p. 348353. [in Russian]

Groessens, E., Conil, R., and Hennebert, M., 1982, Le Dinantien du sondage de Saint-Ghislain: Stratigraphie et paléontologie: Mémoires pour Servir à l'Explication des Cartes Géologiques et Minières de la Belgique, v. 22 (for 1979), p. 1-137.

Grossman, E.L., Yancey, T.E., Jones, T.E., Bruckschen, P., Chuvashov, B. Mazzullo, S.J., and Mii, H.-S., 2008, Glaciation, aridification, and carbon sequestration in the Permo-Carboniferous: The isotopic record from low latitudes: Palaeogeography, Palaeoclimatology, Palaeoecology, v. 268, p. 222-233, https://doi.org/10.1016/j.palaeo.2008.03.053.

Groves, J.R., Wang, Y., Qi, Y., Richards, B.C., Ueno, K., and Wang, X., 2012, Foraminiferal biostratigraphy of the Visean-Serpukhovian (Mississippian) boundary interval at slope and platform sections in southern Gizhou (South China): Journal of Paleontology, v. 86, p. 753-774, https://doi.org/ 10.1666/11-111.1.

Gulbranson, E.L., Montañez, I.P., Schmitz, M.D., Limarino, C.O., Isbell, J.L., Marenssi, S.A., and Crowley, J.L., 2010, High-precision U-Pb calibration of Carboniferous glaciation and climate history, Paganzo Group, NW Argentina: Geological Society of America Bulletin, v. 122, p. 1480-1498.

Hallett, D., 1971, Foraminifera and algae from the Yoredale 'series' (ViséanNamurian) of Northern England, in Congrès International de Stratigraphie du Carbonifère, 6th, Sheffield, 1967, Compte Rendu 3: Sheffield, UK, Sheffield University, p. 873-901.

Hammer, Ø., 2016, PAST 4: Paleontological Statistics Software Package: Natural History Museum, University of Oslo, Norway, https://www.nhm.uio. no/english/research/infrastructure/past/.

Hance, L., Poty, E., and Devuyst, F.-X., 2001, Stratigraphie séquentielle du Dinantien type (Belgique) et correlation avec le nord de la France (Boulonnais, Avesnois): Bulletin de la Société Géologique de France, v. 172, p. 411-426, https://doi.org/10.2113/172.4.411.

Haq, B.U., and Schutter, S.R., 2008, A chronology of Paleozoic sea-level changes: Science, v. 322, no. 5898, p. 64-68, https://doi.org/10.1126/science.1161648.

Harris, A.G., Brenckle, P.L., Baesemann, J.F., Krumhardt, A.P., and Gruzlovic, P.D., 1997, Comparison of conodont and calcareous microfossil biostratigraphy and lithostratigraphy of the Lisburne Group (Carboniferous), Sadlerochit Mountains, Northeast Brooks Range, Alaska, in Dumoulin, J.A., and Gray, J.E., eds., Geologic Studies in Alaska by the U.S. Geological Survey, 1995: U.S. Geological Survey Professional Paper 1574, p. 195-219.

Higgins, A.C., 1981, The distribution of conodonts in relation to the paleogeography of late Visean-Namurian time, in Neale, J.W., and Brasier, M.D., eds., Microfossils from Recent and Fossil Shelf Seas: Chichester, UK, Ellis Horwood Limited, p. 37-51.

Hill, D., 1973, Lower Carboniferous corals, in Hallam, A., ed., Atlas of Palaeobiogeography: Amsterdam, Elsevier, p. 133-142.

Hill, D., 1981, Treatise on Invertebrate Paleontology, Part F, Coelenterata, Supplement 1, Rugosa and Tabulata, 2 Volumes: Boulder, Colorado, and Lawrence, Kansas, Geological Society of America (and University of Kansas Press), 762 p. (2 vols.)

Horbury, A.D., and Adams, A.E., 1996, Microfacies associations in Asbian carbonates: An example from the Urswick Limestone Formation of the southern Lake District, northern England, in Strogen, P., Somerville, I.D., and Jones, G.L., eds., Recent Advances in Lower Carboniferous Geology: Geological Society London, Special Publication 107, p. 221-237.

Isbell, J.L., Miller, M.F., Wolfe, K.L., and Lenaker, P.A., 2003, Timing of late Paleozoic glaciation in Gondwana: Was glaciation responsible for the development of northern hemisphere cyclothems?, in Chan, M.A., and Archer, A.W., eds., Extreme Depositional Environments: Mega end Members in Geologic Time: Geological Society of America Special Paper 370, p. 5-24, https://doi.org/10.1130/0-8137-2370-1.5.

Ivanova, E.A., 1973, [On the stratigraphy of the middle and late Visean from eastern slope of southern Urals]: Akademiya Nauk SSSR, Uralskii 
Nauchnyi Tsentr, Trudy Instituta Geologii i Geokhimii, v. 82, p. 18-86. [in Russian]

Jansa, L.F., and Mamet, B.L., 1984, Offshore Viséan of eastern Canada: Paleogeographic and plate tectonic implications, in Manger, W.L., Macqueen, R.W., Nassichuk, W.W., Pfefferkorn, H.W., and Sutherland, P.K., eds., Congrès International de Stratigraphie du Carbonifère, 9th, Washington and Champaign-Urbana 1981, Compte Rendu 3: Carbondale, Southern Illinois University Press, p. 205-214.

Jansa, L.F., Mamet, B.L., and Roux, A., 1978, Viséan limestones from the Newfoundland Shelf: Canadian Journal of Earth Sciences, v. 15, p. 1422-1436.

Johnson, J.H., 1956, Archaeolithophyllum, a new genus of Paleozoic coralline algae: Journal of Paleontology, v. 30, p. 53-55.

Johnson, J.H., 1966, New Mississippian algae from Alberta: Journal of Paleontology, v. 40, p. 1385-1399.

Johnson, J.H., and Konishi, K., 1956, A review of Mississippian algae: Quarterly of the Colorado School of Mines, v. 51, p. 1-84.

Jutras, P., Prichonnet, G., and Utting, J., 2001, Newly identified Carboniferous units (the Pointe Sawyer and Chemin-des-Pêcheurs formations) in the Gaspe Peninsula, Quebec: Implications regarding the evolution of the northwestern sector of the Maritimes Basin: Canadian Journal of Earth Sciences, v. 38, p. 1-19, https://doi.org/10.1139/cjes-38-1-1.

Jutras, P., McLeod, J.R., and Utting, J., 2015, Sedimentology of the lower Serpukhovian (Upper Mississippian) Mabou Group in the Cumberland Basin of eastern Canada: Tectonic, halokinetic, and climatic implications: Canadian Journal of Earth Sciences, v. 52, p. 1150-1168, https://doi.org/10.1139/cjes-2015-0062.

Kiparisova, L.D., Markovski, B.P., and Radchenko, G.R., 1956, [Material for palaeontology (new families and genera)]: Trudy VSEGEI, Paleontologia, n. ser., v. 12, p. 1-354 [in Russian].

Konishi, K., 1956, Anatolipora, a new dasycladacean genus, and its algal associates from the lower Carboniferous of Japan: Quarterly of the Colorado School of Mines, v. 51, p. 109-127.

Korn, D., Titus, A.L., Ebbighausen, V., Mapes, R.H., and Sudar, M.N., 2012, Early Carboniferous (Mississippian) ammonoid biogeography: Geobios, v. 45, p. 67-77, https://doi.org/10.1016/j.geobios.2011.11.013.

Krainer, K., and Vachard, D., 2015, Late Viséan (MFZ14) foraminifers and algae from the Kirchbach Limestone (Carnic Alps, Austria) and geological implications: Facies, v. 61, p. 1-23.

Kroner, U., and von Romer, R.L., 2013, Two plates-Many subduction zones: The Variscan Orogeny reconsidered: Gondwana Research, v. 24, p. 298 329, https://doi.org/10.1016/j.gr.2013.03.001.

Kulik, E.L., 1973, [Cyanophyta], in Einor, O.L., ed., [Stratigraphy and Fauna from the Carboniferous of the Shartym River (Southern Urals)]: Lvov, Ukraine, Uralskoe Geologicheskoe Upravlenie, Kievskii Ordena Lenina Gosudarstvennyi Universitet, Izdatelskoe Obedisenie 'Vishcha Shkola,' p. 39-48. [in Russian]

Landing, E., 2005, Early Paleozoic Avalon-Gondwana unity: An obituaryResponse to 'Palaeontological evidence bearing on global OrdovicianSilurian continental reconstructions' by R.A. Fortey and L.R.M. Cocks: Earth-Science Reviews, v. 69, 169-175, https://doi.org/10.1016/j.earscirev.2004.10.002

Lee, G.W., 1912, The British Carboniferous Trepostomata; Memoirs Geological Survey Great Britain, Paleontology, v. 1, p. 135-195.

Le Pichon, X., 1977, The fit of the continents around the North Atlantic Ocean: Tectonophysics, v. 38, p. 169-209.

Lewis, H.P., 1935, The lower Carboniferous corals of Nova Scotia: Annals and Magazine of Natural History, v. 10, p. 118-142.

Lipina, O.A., 1970, [Evolution of biserial rectilinear early Carboniferous Foraminifera]: Akademy of Sciences USSR, Questions of Micropaleontology, v. 13, p. 3-29. [in Russian]

Loeblich, A.R., Jr., and Tappan, H., 1987, Foraminiferal Genera and Their Classification, 2 Volumes: New York, Van Nostrand Reinhold Company, 970 p.

Malakhova, N.P., 1973, [About the age and stratigraphic position of the Gusikhinsky Formation of the southern Urals]: Akademiya Nauk SSSR, Uralskii Nauchnyi Tsentr, Trudy Instituta Geologii i Geokhimii, v. 82, p. 127-185. [in Russian]

Malakhova, N.P., 1975, [Foraminifera of the lower Visean on the eastern slope of the southern Urals]: Akademiya Nauk SSSR, Uralskii Nauchnyi Tsentr, Trudy Instituta Geologii i Geokhimii, v. 112, p. 5-70. [in Russian]

Mamet, B.L., 1968, Sur une microfaune du Viséen supérieur de Terre Neuve: Naturalist Canadien, v. 95, p. 1357-1372.

Mamet, B.L., 1970, Carbonate microfacies of the Windsor Group (Carboniferous) Nova Scotia and New Brunswick: Geological Survey Canada, Paper $70-21$, p. $1-121$

Mamet, B.L., 1973, Microfaciès Viséens du Boulonnais (Nord, France): Revue de Micropaléontologie, v. 16, p. 101-124.

Mamet, B.L., 1974a, Sur deux Dasycladacees carboniferes des Cordilleres nord-americaines: Revue de Micropaléontologie, v. 17, p. 38-44.

Mamet, B.L., 1974b, Taxonomic note on Carboniferous Endothyracea: Journal of Foraminiferal Research, v. 4, p. 200-204.
Mamet, B.L., 1974c, Une zonation par foraminifères du Carbonifère inférieur de la Téthys occidentale, in Josten K.-H., ed., Congrès International de Stratigraphie et Géologie du Carbonifère, 7th, Krefeld 1971, Compte Rendu 3: Krefeld, Germany, Geologischen Landesamt Nordrhein-Westtfalen, p. 391408 .

Mamet, B.L., 1975, Viseidiscus, un nouveau genre de Planoarchaediscinae (Archaediscidae, foraminifères): Comptes Rendus Sommaires des Séances de la Société Géologique de France, v. 2, p. 48-49.

Mamet, B.L., 1976, An atlas of microfacies in Carboniferous carbonates of the Canadian Cordillera: Bulletin of the Geological Survey Canada, v. 255, p. $1-132$

Mamet, B.L., 1977, Foraminiferal zonation of the lower Carboniferous: Methods and stratigraphic implications, in Kauffman, E.K., and Hazel, J.E., eds., Concepts and Methods of Biostratigraphy: Stroudsburg, Pennsylvania, Dowden, Hutchinson and Ross, p. 445-462.

Mamet, B.L., 1981, Note taxonomique sur Zellerinella, nomen novum (Foraminiferida, Eostaffellidae): Geobios, v. 14, p. 140

Mamet, B.L., 1991, Carboniferous calcareous algae, in Riding, R., ed., Calcareous Algae and Stromatolites: Berlin-Heidelberg, Germany, Springer, p. 370-451.

Mamet, B.L., 1992, Paléogéographie des algues calcaires marines Carbonifères: Canadian Journal of Earth Sciences, v. 29, p. 174-194.

Mamet, B.L., 1995a, Amarellina, une paleosiphonocladale (algue, verte) nouvelle du Carbonifère maghrebin: Bulletin Centres Recherche ExplorationProduction Elf Aquitaine, v. 19, p. 293-299.

Mamet, B.L., 1995b, Hortonella uttingii, gen. nov., sp. nov., Udotéacées? (algues vertes?) du Carbonifère inférieur: Canadian Journal of Earth Sciences, v. 32, p. 1267-1272.

Mamet, B.L., 1997, Pseudokulikia, a new Viséan green alga from Morocco: Revue de Micropaléonotologie, v. 40, p. 331-338.

Mamet, B.L., 2002, Carboniferous marine algae, lower part of Akiyoshi Limestone Group, Japan, in Hills, L.V., Henderson C.M., and Bamber, E.W., eds., Carboniferous and Permian of the World: Canadian Society of Petroleum Geologists Memoir 19, p. 492-528.

Mamet, B.L., and Pinard, S., 1992, Note sur la taxonomie des petits foraminifères du Paléozoïque supérieur-A taxonomic note on upper Paleozoic smaller Foraminifera: Bulletin de la Société Belge de Géologie, v. 99 (for 1990), p. 373-398.

Mamet, B.L., and Preat, 2010, Un atlas d'algues calcaires Carbonifère, Alaska arctique: Brussels, Belgium, Carnets de Géologie, Université libre de Bruxelles, $60 \mathrm{p}$.

Mamet, B.L., and Roux, A., 1974, Sur quelques algues tubulaires scalariformes de la Tethys paleozoique: Revue de Micropaléontologie, v. 17, p. 134-156.

Mamet, B.L., and Roux, A., 1975a, Dasycladacees devoniennes et carbonifères de la Tethys occidentale: Revista Española de Micropaleontología, v. 7, p. 245-295.

Mamet, B.L., and Roux, A., 1975b, Algues devoniennes et carboniferes de la Tethys occidentale, troisieme partie: Revue de Micropaléontologie, v. 18, p. 134-187.

Mamet, B.L., and Roux, A., 1978, Algues viseennes et namuriennes du Tennessee (Etats-Unis): Revue de Micropaleontologie, v. 2, p. 68-97.

Mamet, B.L., and Roux, A., 1983, Algues dévono-carbonifères de l'Australie: Revue de Micropaléontologie, v. 26, p. 63-131.

Mamet, B.L., and Roux, A., 1984, Poncetellina nomen novum (algue verte): Revue de Micropaléontologie, v. 27, p. 138.

Mamet, B.L., and Rudloff, B., 1972, Algues carbonifères de la partie septentrionale de l'Amérique du Nord: Revue de Micropaléontologie, v. 15, p. 75-114.

Mamet, B.L., and Sebbar, A., 1998, Lemosquetella annulata nov. gen., nov. sp., une algue verte viseenne du bassin de Bechar, Algerie: Geobios, v. 31, p. $145-149$.

Mamet, B.L., and Skipp, B., 1970a, Lower Carboniferous Foraminifera: Preliminary zonation and stratigraphic implications for the Mississippian of North America, in Congrès International de Stratigraphie du Carbonifère, 6th, Sheffield 1967, Compte Rendu 3: Sheffield, UK, University of Sheffield, p. 1124-1246.

Mamet, B.L., and Skipp, B., 1970b, Preliminary foraminiferal correlations of early Carboniferous strata in the North American Cordillera: Colloque sur la stratigraphie du Carbonifère: Colloques et Congrès de l'Université de Liège, v. 55, p. 327-348.

Mamet, B.L., and Skipp, B., 1979, Lower Carboniferous Foraminifera-Paleogeographical implications, regional Carboniferous biostratigraphy of modern climates, in Meyen, S.V., et al., eds., Congrès International de Stratigraphie du Carbonifère, 8th, Moscow 1975, Compte Rendus 2: Moscow, Publishing Office Nauka, p. 48-66.

Mamet, B.L., Mikhailoff, N., and Mortelmans, G., 1970, La stratigraphie du Tournaisien et du Viséen inférieur de Landelies: Comparaison avec les coupes du Tournaisis et du bord nord du synclinal de Namur: Mémoires de la Société Belge de Géologie, de Paléontologie et d'Hydrologie, sér. 8, v. 9 , p. $1-81$. 
Mamet, B.L., Roux, A., and Nassichuk, W.W., 1987, Algues carbonifères et permiennes de l'Arctique canadien: Geological Survey of Canada, Bulletin 342, p. 1-143.

Mamet, B.L., Pinard, S., and Armstrong, A.K., 1993, Micropaleontological zonation (foraminifers, algae) and stratigraphy, Carboniferous Peratrovich Formation, southeastern Alaska: U.S. Geological Survey Bulletin, v. 2031, p. 1-32.

Marfenkova, M.M., 1978, [Foraminifera and stratigraphy of lower and middle Visean from southern Kazakhstan]: Proceedings of the Institute of Geology and Geophysics, Siberian Filiale of the Academy of sciences USSR, v. 386, p. 78-99. [in Russian]

Marfenkova, M.M., 1991, [The Marine Carboniferous of Kazakhstan, Part 2, Stratigraphy, Zonal Sequence and Foraminifers]: Alma-Ata, Kazakhstan, 'Zylym,' Akademiya Nauk Kazakhskoi SSR, Institut Geologicheskikh Nauk, 197 p. [in Russian]

Maslov, V.P., 1950, [Fossil red algae for the stratigraphy of USSR]: Doklady Akademii Nauk SSSR, v. 70, p. 75-301. [in Russian]

Maslov, V.P., 1956, [Fossil calcareous algae from USSR]: Trudy Instituta Geologicheskikh Nauk, Akademiya Nauk SSSR, v. 160, p. 1-301. [in Russian]

McCoy, F., 1849, On some new genera and species of Palaeozoic corals and Foraminifera: Annals and Magazine of Natural History, ser. 2, v. 3 p. 1-20, 119-136.

McCoy, F., 1851, A description of some New Mountain Limestone fossils: Annals and Magazine of Natural History, ser. 2, v. 7, p. 167-175.

McKerrow, W.S., MacNiocaill, C., Ahlberg, P., Clayton, G., Cleal, C.J., and Eager, R.M.C., 2000, The late Palaeozoic relations between Gondwana and Laurussia, in Franke, W., Haak, V., Oncken, O., and Tanner, D., eds. Quantification and Modelling in the Variscan Belt: Geological Society London Special Publication 179, p. 9-20, https://doi.org/10.1144/GSL.SP.2000. 179.01.03.

Mikhailov, A., 1935, [To the question of the phylogeny of the Carboniferous Foraminifera]: Izvestiya Leningradskogo Geologo-Gidro-Geodezicheskogo Tresta, v. 2/3 (7/8), p. 38-42. [in Russian]

Mikhailov, A., 1939, [On characteristic genera of early Carboniferous foraminifers in territories of the USSR: The lower Carboniferous deposits of the northwestern limb of Moscow basin]: Sbornik Leningradskogo Geologicheskogo Upraleniya, v. 3, p. 47-62. [in Russian]

Miklukho-Maklay, A.D., 1960, [New early Carboniferous endotyrids], in Markovsky, B.P., ed., [New Species of Ancient Plants and Invertebrates of the USSR]: Moscow, Gosgeoltekhizdat, p. 140-151. [in Russian]

Millward, D., Davies, S.J., Williamson, F., Curtis, R., Kearsey, T.I., Bennett, C.E., Marshall, J.E.A., and Browne, M.A.E., 2018, Early Mississippian evaporites of coastal tropical wetlands: Sedimentology, v. 65, p. 2278 2311, https://doi.org/10.1111/sed.12465.

Milne-Edwards, H., and Haime, J., 1850, A Monograph of the British fossil corals: London, Palaeontographical Society, $71 \mathrm{p}$.

Mitchell, W.I., 1992, The origin of upper Palaeozoic sedimentary basins in Northern Ireland and relationships with the Canadian Maritime provinces, in Parnell, J., ed., Basins on the Atlantic Seaboard: Petroleum Geology, Sedimentology and Basin Evolution: Geological Society London Special Paper 6, p. 191-202.

Mitchell, W.I., and Mitchell, M., 1983, The lower Carboniferous (upper Viséan) succession at Benburb, Northern Ireland: London HMSO, Institute of Geological Sciences, Report 82/12, 9 p.

Möller, V. von, 1878, Die spiral-gewundenen Foraminiferen des russischen Kohlenkalks: Mémoires de l'Académie Impériale des Sciences de St. Pétersbourg, ser. 7, v. 25, no. 9, p. 1-147.

Möller, V. von, 1879, Die Foraminiferen des russischen Kohlenkalks: Mémoires de l'Académie Impériale des Sciences de St. Pétersbourg, ser. 7, v. 27 , no. 5 , p. 1-131.

Mory, A.J., Redfern, J., Martin, J.R., Fielding, C.R., Frank, T.D., and Isbell, J.L., 2008, A review of Permian-Carboniferous glacial deposits in Western Australia: Geological Society of America, Special Paper, v. 441, p. 29-40, https://doi.org/10.1130/2008.2441(02)

Murphy, J.B., Fernández-Suárez, J., Keppie, J.D., and Jeffries, T.E., 2004, Contiguous rather than discrete Paleozoic histories for the Avalon and Meguma terranes based on detrital zircon data: Geology, v. 32, p. 585-588, https:// doi.org/10.1130/G20351.1.

Nance, R.D., Gutiérrez-Alonso, G., Keppie, J.D., Linnemann, U., Murphy, J.B., Quesada, C., Strachan, R.A., and Woodcock, N.H., 2012, A brief history of the Rheic Ocean: Geoscience Frontiers, v. 3, p. 125-135, https://doi.org/10. 1016/j.gsf.2011.11.008.

Neves, R., Gueinn, K.J., Clayton, G., Ioannides, N., and Neville, R.S.W., 1972, A scheme of miospore zones for the British Dinantian in Josten K.-H., ed. Congrès International de Stratigraphie et Géologie du Carbonifère, 7th, Krefeld 1971, Compte Rendu 1: Krefeld, Germany, Geologischen Landesamt Nordrhein-Westtfalen, p. 347-353.

Neves, R., Gueinn, K.J., Clayton, G., Ioannides, N., Neville, R.S.W., and Kruszewska, K., 1973, Palynological correlations within the lower
Carboniferous of Scotland and northern England: Transactions of the Royal Society of Edinburgh, v. 69, p. 23-70.

Nicholson, H.A., and Etheridge, R., 1878, A Monograph of the Silurian Fossils of the Girvan District, Ayrshire, with Special Reference to Those Contained in the 'Gray Collection,' I: Blackwood, Edinburgh London, 341 p.

Okimura, Y., 1965, Endothyroid Foraminifera: Endothyranopsis from Japan Geological Report of the Hiroshima University, v. 4, p. 253-264.

Orbigny, A.d', 1849, Notes sur des Polypiers Fossils: Paris, Victor Masson, 12 $\mathrm{p}$

Perret, M.F., and Vachard, D., 1977, Algues et pseudo-algues des calcaires serpoukhoviens d'Ardengost (Hautes-Pyrenees): Annales de Paléontologie (Invertébrés), v. 3, p. 85-156.

Petryk, A.A., and Mamet, B.L., 1972, Lower Carboniferous algal microflora, southwestern Alberta: Canadian Journal of Earth Sciences, v. 9, p. 767-802.

Phillips, J., 1846, On the remains of microscopic animals in the rocks of York shire: Proceedings of the Geological and Polytechnic Society of the West-Riding of Yorkshire, August 1845, p. 274-302.

Pia, J. von, 1937, Die wichtigsten Kalkalgen des Jungpaläozoikums und ihre geologische Bedeutung, in Jongmans, W.J., ed., Compte Rendu du 2e Congrès Avancement Etudes de Stratigraphie du Carbonifère, Heerlen 1935 Liège, Belgium, Vaillant-Carmanne S.A., p. 765-856.

Pille, L., 2008, Foraminifères et algues calcaires du Mississippien supérieur (Viséen supérieur-Serpukhovien): Rôles biostratigraphique, paléoécologique et paléogéographique aux échelles locale, régionale et mondiale, 3 volumes [Ph.D. dissertation]: Lille, France, Université de Lille, $327+256$ $+156 \mathrm{p}$.

Pille, L., and Vachard, D., 2011, Diploporaceae (calcareous green algae Dasycladales) from the late Visean (Mississippian) of Montagne Noire (southern France): Revue de Micropaléontologie, v. 54, p. 1-30, https://doi.org/10. 1016/j.revmic.2009.02.001

Pirlet, H., and Conil, R., 1977, L'évolution des Archaediscidae viséens: Bulletin de la Société Belge de Géologie de Paléontologie et d'Hydrologie, v. 82 (for 1973), p. 241-300

Plummer, H.J., 1930, Calcareous Foraminifera in the Brownwood shale near Bridgeport, Texas: University of Texas Bulletin 3019, p. 5-21.

Pokorny, V., 1951, [The Middle Devonian Foraminifera of Celechovice, Czechoslovakia]: Vestnik Kraslovske Ceske Spolecnosti Nauk, Trida Matematicko-prirodovedecka, v. 9, p. 1-29. [in Russian]

Poty, E., 2002, Stratigraphy and paleobiology of Carboniferous rugose corals of Nova Scotia, in Hicks, L.V., Henderson, C.M., and Bamber, E.W., eds., Carboniferous and Permian of the World: Canadian Society of Petroleum Geologists Memoir 19, p. 580-587.

Prentice, J.E., 1949, The Hemisphaericus-like gigantellids of the southern Pennines: Proceedings of the Yorkshire Geological Society, v. 27, p. 247-269.

Purnell, M.A., and von Bitter, P.H., 1992, Vogelgnathus Norby and Rexroad (Conodonta): New species from the lower Carboniferous of Atlantic Canada and northern England: Journal of Paleontology, v. 66, p. 311-332.

Qiao, L., and Shen, S.Z., 2014, Global paleobiogeography of brachiopods during the Mississippian-Response to the global tectonic reconfiguration, ocean circulation, and climate changes: Gondwana Research, v. 26, p. 1173-1185, https://doi.org/10.1016/j.gr.2013.09.013.

Qiao, L., and Shen, S.Z., 2015, A global review of Late Mississippian (Carboniferous) Gigantoproductus (Brachiopoda) faunas and their paleogeographical, paleoecological, and climatic implications: Palaeogeography, Palaeoclimatology, Palaeoecology, v. 420, p. 128-137, https://doi.org/10. 1016/j.palaeo.2014.12.011

Ramsbottom, W.H.C., 1973, Trangressions and regressions in the Dinantian: A new synthesis of British Dinantian stratigraphy: Proceedings of the Yorkshire Geological Society, v. 39, p. 567-607.

Raup, D.M., and Crick, R.E., 1979, Measurement of faunal similarity in paleontology: Journal of Paleontology, v. 53, p. 1213-1227.

Rauzer-Chernousova, D.M., 1938, [The upper Paleozoic Foraminifera of Samara Bend and the Trans-Volga región]: Proceedings of the Geological Institute of the USSR Academy of Sciences (Leningrad), v. 7, p. 69-168. [in Russian]

Rauzer-Chernousova, D.M., 1948a, [Contributions to the foraminiferal fauna of the Carboniferous deposits of central Kazakhstan]: Academy of Sciences USSR Proceedings Institute of Geological Sciences, v. 66, Geologicheskaya Seriya 21, p. 1-28. [in Russian]

Rauzer-Chernousova, D.M., 1948b, [Genus Haplophragmella and related forms]: Akademiya Nauk SSSR, Trudy Instituta Geologicheskikh Nauk, v. 62, Geologicheskaya Seriya 19, p. 159-165. (in Russian)

Rauzer-Chernousova, D.M., and Fursenko, A.V., 1959, [Principles of Paleontology, Part 1, Protozoa]: Moscow, Akademiya Nauk SSSR, 368 p. [in Russian]

Rauzer-Chernousova, D.M., Belyaev, G., and Reitlinger, E., 1936, [Upper Paleozoic Foraminifera of the Pechora región]: Proceedings of the Polar Commission AS USSR, v. 28, p. 159-232. [in Russian] 
Reitlinger, E.A., 1950, [Foraminifera of the middle Carboniferous deposits of the central part of the Russian Platform (exclusive of family Fusulinidae)]: Academy of Sciences USSR Proceedings Institute of Geological Sciences, v. 126, p. 1-128. [in Russian]

Reitlinger, E.A., 1954, [Devonian foraminifers from the eastern part of the Russian Platform]: Paleontologichevskii Sbornik, Vsesoyuznogo Neftyanogo Nauchno-Issledovatel'skogo Geologorazvedochnogo lnstituta, v. 1, p. 4151. [in Russian]

Reitlinger, E.A., 1956, [New family Lasiodiscidae]: Academy of Sciences USSR Questions of Micropaleontology, v. 1, p. 69-78. [in Russian]

Reitlinger, E.A., 1963, [About paleontological criteria for establishing the boundaries of the lower Carboniferous division (based on the fauna of Foraminifera)]: Academy of Sciences USSR Questions of Micropaleontology, v. 7, p. 22-56. [in Russian]

Reitlinger, E.A., 1966, [Some questions on the classification and evolution of endothyrines and primitive fusulinines]: Academy of Sciences USSR Questions of Micropaleontology, v. 10, p. 39-67. [in Russian]

Reitlinger, E.A., 1971, [Some problems of systematics in the light of evolutionary stage of upper Paleozoic foraminifers]: Academy of Sciences USSR Questions of Micropaleontology, v. 14, p. 3-16. [in Russian]

Reitlinger, E.A., 1980, [On boundary between the Bogdanovsky and Krasnopolyansky horizons (foraminifers of the Homoceras zone)]: Academy of Sciences USSR Questions of Micropaleontology, v. 23, p. 23-38. [in Russian]

Reitlinger, E.A., and Melnikova, A.S., 1977, [On characteristics of Fusulinidea of the Serpukhovian time]: Academy of Sciences USSR Questions of Micropaleontology, v. 20, p. 68-80. [in Russian]

Rexroad, C.B., 1957, Conodonts from the Chester Series in the type area of southwestern Illinois: Illinois State Geological Survey, Report of Investigations, v. 199, p. 1-143.

Rich, M., 1980, Carboniferous calcareous Foraminifera from northeastern Alabama, south-central Tennessee, and northwestern Georgia: Cushman Foundation for Foraminiferal Research, Special Publication 18, $62 \mathrm{p}$.

Rich, M., 1986, Foraminifera, stratigraphy and regional interpretation of the Bangor Limestone in northwestern Georgia: Journal of Foraminiferal Research, v. 16, p. 110-134.

Ross, C.A., 1995, Permian fusulinaceans, in Scholle, P.A., et al., eds., Permian of Northern Pangea, Volume 1, Paleogeography, Paleoclimate, Stratigraphy: Berlin, Springer-Verlag, p. 167-185.

Rothpletz, A., 1913, Uber die Kalkalgen, Spongiostromen und einige andere Fossilien aus dem Obersilur Gotlands: Sver Geol Undersokning, v. 10, p. 1-54.

Roux, A., 1979, Revision du genre Epimastopora 'Pia 1922' (Dasycladaceae): Bulletin Centres Recherche Exploration-Production Elf Aquitaine, v. 3, p. $803-810$.

Roy, J.L., 1973, Latitude maps of the eastern North America-western Europe paleoblock: Geological Survey Canada Paper 71-23, 322 p.

Rozovskaya, S.E., 1961, [The taxonomy of the families Endothyridae and Ozawainellidae]: Paleontologicheskii Zhurn, v. 3, p. 19-21. [in Russian]

Saltovskaya, V.D., 1984, [Some calcareous algae from the Palaeozoic of Tadzhikistan], in Dzhalilov, M.R., ed., [New Species of Fossil Fauna and Flora of Tadzhikistan]: Dushambe, Russia, Akademiya Nauk Tadzhiskoi SSR, Institut Geologii, p. 141-160. [in Russian]

Schubert, R.J., 1908, Beiträge zu einer natürlichen Systematik der Foraminiferen: Neues Jahrbuch für Mineralogie, Geologie und Paläontologie, v. 25, p. 232-260.

Schubert, R.J., 1921, Palaeontologische Daten zur Stammesgeschichte der Protozoen: Paläontologische Zeitschrift, v. 3, p. 129-188.

Scotese, C.R., 2015, Atlas of plate tectonic reconstructions: Technical report: https://www.researchgate.net/profile/Christopher_Scotese3 (accessed June 2016).

Shlykova, T.I., 1969, [New early Carboniferous foraminiferal genus]: Academy of Sciences USSR Questions of Micropaleontology, v. 12, p. 47-50. [in Russian]

Shvetsov, M.S., and Birina, L.M., 1935, [On the problems of the petrology and origin of the Oka limestones of the Mikhailov-Aleksin área]: Trudy Moskovskogo Geologicheskogo Tresta, v. 10, p. 1-86. [in Russian]

Simonova, Y.A., and Zub, V.V., 1975, New representatives of the family Quasiendothuridae from the middle and upper Visean deposits of the northern Tien-Shan and Lesser Karatau: Kazakh Polytechnic Institute, Geology, v. 9, p. 19-35. [in Russian]

Skompski, S., 1986, Upper Viséan calcareous algae from the Lublin Coal Basin: Acta Geologica Polonica, v. 36, p. 251-280.

Smith, G.A., Briden, J.C., and Drewry, G.E., 1973, Phanerozoic world maps: Special Papers in Palaeontology, v. 12, p. 1-42.

Smith, L.B., and Read, J.F., 2000, Rapid onset of late Paleozoic glaciation on Gondwana: Evidence from Upper Mississippian strata of the Midcontinent, United States: Geology, v. 28, p. 279-282.

Smith, S., 1928, The Carboniferous coral Nemistium edmundsi genus et sp. nov.: Annals and Magazine of Natural History, v. 10, p. 112-120.
Sollas, W.J., 1921, On Saccammina carteri Brady, and the minute structure of the foraminiferal shell: Quarterly Journal of the Geological Society of London, v. 77, p. 193-212.

Sosipatrova, G.P., 1962, [Foraminifers from the upper Paleozoic deposits of Taimyr]: Collection of Articles in Paleontology and Stratigraphy NINGA, v. 30, p. 35-72. [in Russian]

Stampfli, G.M., and Borel, G.D., 2002, A plate tectonic model for the Paleozoic and Mesozoic constrained by dynamic plate boundaries and restored synthetic oceanic isochrons: Earth and Planetary Science Letters, v. 196, p. 17-33, https://doi.org/10.1016/S0012-821X(01)00588-X.

Stampfli, G.M., Hochard, C., Verard, C., Wilhem, C., and von Raumer, J., 2013, The formation of Pangea: Tectonophysics, v. 593, p. 1-19, https:// doi.org/10.1016/j.tecto.2013.02.037.

Stephenson, M.H., Angiolini, L., Cózar, P., Jadoul, F., Leng, M.J., Millward, D., and Chenery, S., 2010, Northern England Serpukhovian (early Namurian) farfield responses to southern hemisphere glaciation: Journal of the Geological Society, London, v. 167, p. 1171-1184, https://doi.org/10.1144/ 0016-76492010-048.

Strank, A.R.E., 1982, Holkeria gen. nov., a foraminifer characteristic of the Holkerian Stage of the British Dinantian: Proceedings of the Yorkshire Geological Society, v. 44, p. 145-151.

Strank, A.R.E., 1983, New stratigraphically significant Foraminifera from the Dinantian of Great Britain: Palaeontology, v. 26, p. 435-442.

Termier, G., and Termier, H., 1950, Paléontologie Marocaine, Tome 2, Invertébrés de l'ère Primaire, Fasc. 1, Foraminifères, Spongiaires et Coelentéré: Paris, Hermann et Cie, 218 p.

Termier, G., Termier, H., and Vachard, D., 1977, Étude comparative de quelques Ischyrosponges: Géologie Méditerranéenne, v. 4, p. 139-180.

Thompson, M.L., 1942, New genera of Pennsylvanian fusulinids: American Journal of Science, v. 240, p. 403-420.

Thompson, M.L., 1951, New genera of fusulinid Foraminfiera: Contributions of the Cushman Foundation for Foraminiferal Research, v. 2, 115-118.

Thomson, J., and Nicholson, H.A., 1876, Contributions to the study of the chief generic types of the Palaeozoic corals: Annals and Magazine of Natural History, v. 17 , p. 123-128, 290-305, 451-461, v. 18, p. 68-73.

Torsvik, T.H., and Cocks, L.R.M., 2004, Earth geography from 400 to $250 \mathrm{Ma}$ : A palaeomagnetic and faunal review: Journal of the Geological Society of London, v. 161, p. 555-572, https://doi.org/10.1144/0016-764903-098.

Torsvik, T.H., and Cocks, L.R.M., 2013, Gondwana from top to base in space and time: Gondwana Research, v. 24, p. 999-1030, https://doi.org/10 1016/j.gr.2013.06.012.

Utting, J., 1987, Palynology of the lower Carboniferous Windsor Group and Windsor-Canso boundary beds of Nova Scotia, and their equivalents in Quebec, New Brunswick and Newfoundland: Geological Survey Canada Bulletin, v. 374, p. 1-93.

Utting, J., and Giles, P.S., 2004, Biostratigraphical implications of new palynological data from the Mississippian of Newfoundland and Nova Scotia, Canada: Association Australasian Paleontologists, Memoir 29, p. $115-160$.

Utting, J., and Giles, P.S., 2008, Palynostratigraphy and lithostratigraphy of Carboniferous Upper Codroy Group and Barachois Group, southwestern Newfoundland: Canadian Journal of Earth Sciences, v. 45, p. 45-67, https://doi.org/10.1139/E07-066.

Vachard, D., 1974, Sur les dasycladacées métaspondyles 'vestibulaires,' à propos d'un de leurs représentants viséens: Eovelebitella occitanica n. gen n. sp.: Comptes Rendus de l'Académie des Sciences de Paris, v. 279, p. $1855-1858$

Vachard, D., 1977, Étude stratigraphique et micropaléontologique (algues et foraminifères) du Viséen de la Montagne Noire (Hérault, France): Mémoires de l'Institut Géologique de l'Université de Louvain, v. 29, p. 111-195.

Vachard, D., 1980, Téthys et Gondwana au Paléozoïque Supérieur: les Données Afghanes; Biostratigraphie, Micropléontologie, Paléogéographie: Paris, Documents et Travaux IGAL, Institut Géologique Albert de Lapparent, $463 \mathrm{p}$.

Vachard, D., 1988, Towards a reasonable classification of the Archaediscidae (Foraminifera, lower middle Carboniferous): Revue de Paléobiologie, special volume 2 , p. 103-123.

Vachard, D., 2016, Macroevolution and biostratigraphy of Palaeozoic foraminifers, in Montenari, M., ed., Stratigraphy \& Timescales: Cambridge, Massachusetts, Elsevier, p. 257-324, https://doi.org/10.1016/bs.sats.2016.10.005

Vachard, D., and Beckary, S., 1991, Algues et foraminiferes bachkiriens des coal balls de la Mine Rosario (Truebano, Leon, Espagne): Revue de Paléobiologie, v. 10, p. 315-357.

Vachard, D., and Cózar, P., 2003, Saccamminopsis, Mississippian carbonate microproblematicum, a possible udoteacean algal gametophyte (Chlorophyta, Siphonales): Geobios, v. 36, p. 421-436, https://doi.org/10.1016/ S0016-6995(03)00042-1.

Vachard, D., and Cózar, P., 2004, Insolentitheca emend., Protoinsolentitheca, n. gen., and Caligellidae emend., permanent cysts of Paleozoic 
foraminifera?: Rivista Italiana di Paleontologia e Stratigrafia, v. 110, p. 591603, https://doi.org/10.13130/2039-4942/5827.

Vachard, D., and Cózar, P., 2005, Falsocalcifolium nov. gen., and revision of the tribe Calcifolieae (Mississippian, incertae sedis algae): Geobios, v. 38, p. 803-822, https://doi.org/10.1016/j.geobios.2004.05.004

Vachard, D., and Cózar, P., 2010, An attempt of classification of the Palaeozoic incertae sedis Algospongia: Revista Española de Micropaleontología, v. 42, p. $129-241$

Vachard, D., and Montenat, C., 1981, Biostratigraphie, micropaleontologie et paleogeographie du Permien de la region de Tezak (Montagnes Centrales d'Afghanistan): Paleontographica B, v. 178, p. 1-88.

Vachard, D., and Tahiri, A., 1991, Foraminifères, algues et pseudoalgues du Viséen de la région d'Oulmès (Maroc): Géologie Méditerranéenne, v. 18, p. 21-41.

Vachard, D., Massa, D., and Strank, A., 1993, The Carboniferous of Al-37 borehole, Cyrenaica, Libya: Biostratigraphical analysis and paleogeographic implications: Revue de Micropaléontologie, v. 36, p. 165-186.

Vachard, D., Pille, L., and Gaillot, J., 2010, Palaeozoic Foraminifera: Systematics, palaeoecology and responses to globlal changes: Revue de Micropaléontologie, v. 53, p. 209-254, https://doi.org/10.1016/j.revmic.2010.10. 001.

Vachard, D., Cózar, P., Aretz, M., and Izart, A., 2016, Late Viséan-early Serpukhovian cyanobacteria and algae from the Montagne Noire (France): Taxonomy and biostratigraphy: Bulletin of Geosciences, v. 91, p. 433-466, https://doi.org/10.3140/bull.geosci.1613.

Vai, G.B., 2003, Development of the palaeogeography of Pangaea from late Carboniferous to early Permian: Palaeogeography, Palaeoclimatology, Palaeoecology, v. 196, p. 125-155, https://doi.org/10.1016/S0031-0182 (03)00316-X.

van Ginkel, A.C., 2010, Systematics of the Eostaffellidae (late Paleozoic Foraminifera): Cushman Foundation for Foraminiferal Research, Special Publication $42,130 \mathrm{p}$.

van Staal, C.R., Dewey, J.F., MacNiocaill, C., and McKerrow, W.S., 1998, The Cambrian-Silurian tectonic evolution of the northern Appalachians and British Caledonides: History of a complex, west and southwest Pacific-type segment of Iapetus, in Blundell, D., and Scott, A.C., eds., Lyell: The Past is the Key to the Present: Geological Society of London Special Publication 143 , p. $199-242$.

Vašíček, M., and Rủžička, B., 1957, Namurian Foraminifera from the OstravaKarviná Coal District: Acta Musei Nationalis Pragae, Series B, Historia Naturalis/Fossil Imprint, v. 13, p. 341-362.

Vaughan, A., 1906, Faunal lists and account of the faunal succession: Quarterly Journal of Geological Society of London, v. 62, p. 295-322.

Vdovenko, M.V., 1954, [Some new types of Foraminifera from the lower Visean strata of the Donetsk basin]: Bulletin of the University of Kyiv, Geology and Geography Series, v. 5, p. 63-76. [in Russian]

Vdovenko, M.V., 1962, [Some new foraminiferal species from upper Visean and lower Namurian deposits of southwestern central Kazakhstan]: Paleontologicheskii Zhurn, v. 1962, p. 41-46. [in Russian]

Vdovenko, M.V., 1971, [A new genus of Foraminifera from the Viséan deposits of the Great Donbass]: Reports of the Academy of Sciences of the Ukrainian SSR, v. 10, p. 877-879. [in Russian]

Vologdin, A.G., 1932, [Archaeocyathids of Siberia, Volume 2, Fauna from the Cambrian limestones of Altai]: Moscow-Leningrad, Gosudarstvennoe Naukno-Teknicheskoe Geologo-Razvedocne Izdateltsvo, 106 p. [in Russian]

von Bitter, P.H., 1976, Paleoecology and distribution of Windsor Group (Viséan-early Namurian) conodonts, Port Hood Island, Nova Scotia, Canada: Geological Association Canada, Special Paper 15, p. 225-241.

von Bitter, P.H., and Austin, R.L., 1984, The Dinantian Taphrognathus transatlanticus conodont Range Zone of Great Britain and Atlantic Canada: Palaeontology, v. 27, p. 95-111.

von Bitter, P.H., and Legrand-Blain, M., 2007, Gigantoproductid brachiopods from the Musquodoboit Limestone of Nova Scotia (upper Windsor Group, Mississippian): Late Asbian-Brigantian palaeobiogeographic connections between eastern Canada and central England, in Wong, T.E., ed., Proceedings, International Congress on Carboniferous and Permian Stratigraphy, 25th, Utrecht, The Netherlands, 10-16 August 2003: Amsterdam, Royal Netherlands Academy of Arts and Sciences, p. 191-203.

von Bitter, P.H, and Plint-Geberls, H.A., 1982, Conodont biostratigraphy of the Codroy Group (lower Carboniferous), southwestern Newfoundland, Canada: Canadian Journal of Earth Sciences, v. 19, p. 193-221.

von Bitter, P.H, and Plint-Geberls, H.A., 1987, Conodonts of the Windsor Group (lower Carboniferous), Magdalen Islands, Quebec, Canada: Journal of Paleontology, v. 61, p. 346-362.

von Bitter, P.H., Sandberg, C.A., and Orchard, M.J., 1986, Phylogeny, speciation, and palaeoecology of the early Carboniferous (Mississippian) conodont genus Mestognathus: Royal Ontario Museum, Life Sciences Contributions, v. $143,115 \mathrm{p}$

von Bitter, P.H., Giles, P.S., and Utting, J., 2007, Biostratigraphic correlation of major cycles in the Windsor and Codroy groups of Atlantic Canada with the Mississippian Stages of Britain and Ireland, in Wong, T.E., ed., Proceedings, International Congress on Carboniferous and Permian Stratigraphy, 25th, Utrecht, The Netherlands, 10-16 August 2003: Amsterdam, Royal Netherlands Academy of Arts and Sciences, p. 513-534.

Waldron, J.W.F., Barr, S.M., Park, A.F., and White, C.E., 2015, Late Paleozoic strike-slip faults in Maritime Canada and their role in the reconfiguration of the northern Appalachian orogen: Tectonics, v. 34, p. 1661-1684, https:// doi.org/10.1002/2015TC003882

Waldron, J.W.F., Giles, P.S., and Thomas, A.K., 2017, Correlation chart for Late Devonian to Permian stratified rocks of the Maritimes Basin, Atlantic Canada: Nova Scotia Department of Energy Open File Report 2017-02, 12 p.

Waldron, J.W.F., Schofield, D.I., and Murphy, J.B., 2018, Diachronous Palaeozoic accretion of peri-Gondwanan terranes at the Laurentian margin, in Wilson, R.W., Houseman, G., McCaffrey, K., Doré, A.G., and Royden, W., eds., Tectonic Evolution: 50 Years of the Wilson Cycle Concept: Geological Society London, Special Publication 470, p. 289-310.

Walsh, G.J., Aleinikoff, J.N., and Wintsch, R.P., 2007, Timing of Alleghanian orogenesis and dome formation in southern Connecticut: American Journal of Science, v. 307, p. 168-215.

Warthin, A.S., Jr., 1930, Micropaleontology of the Wetumka, Wewoka and Holdenville formations: Oklahoma Geological Survey Bulletin 53, p. 1-95.

West, I.M., Brandon, A., and Smith, M.A., 1968, A tidal flat evaporitic facies in the Viséan of Ireland: Journal of Sedimentary Petrology, v. 38, p. 10791093.

Wethered, E., 1886, On the structure and organisms of the Lower Limestone Shales, Carboniferous Limestone and upper limestones of the Forest of Dean: Geological Magazine, v. 3, p. 529-540.

Wood, A., 1940, Two new calcareous algae of the family Dasycladaceae from the Carboniferous Limestone: Proceedings of the Liverpool Geological Society, v. 18, p. 14-18.

Wood, A., 1941, The lower Carboniferous calcareous algae Mitcheldeania Wethered and Garwoodia gen. nov.: Proceedings of the Geological Association, v. 52, p. 216-226.

Wood, A., 1948, Sphaerocodium, a misinterpreted fossil from the Wenlock Limestone: Geological Association Proceedings, v. 59, p. 9-22.

Wood, A., 1964, A new dasycladacean alga, Nanopora, from the lower Carboniferous of England and Kazakhstan: Palaeontology, v. 7, p. 181-185.

Zaninetti, L., and Altiner, D., 1979, La famille des Archaediscidae (Foraminifères): Analyse taxonomique et propositions pour une nouvelle subdivision: Archives des Sciences, Genève, v. 32, p. 163-175.

Zeller, D.E.N., 1953, Endothyroid Foraminifera and ancestral fusulinids from the type Chesterian (Upper Mississippian): Journal of Paleontology, v. 27, p. $183-199$.

Ziegler, P.A., 1978, Northwestern Europe: Tectonics and basin development: Geologie en Mijnbouw, v. 57, p. 586-626.

Accepted: 5 February 2021 